\title{
Redox regulation of transient receptor potential channels.
}

$\operatorname{AUTHOR}(S)$ :

Kozai, Daisuke; Ogawa, Nozomi; Mori, Yasuo

CITATION:

Kozai, Daisuke ... [et al]. Redox regulation of transient receptor potential channels.. Antioxidants \& redox signaling 2014, 21(6): 971-986

ISSUE DATE:

2014-08-20

URL:

http://hdl.handle.net/2433/189437

\section{RIGHT:}

This is a copy of an article published in the Antioxidants \& Redox

Signaling (c) 2014 Mary Ann Liebert, Inc.; Antioxidants \& Redox Signaling is available online at: http://online.liebertpub.com. 


\title{
Redox Regulation of Transient Receptor Potential Channels
}

\author{
Daisuke Kozai, ${ }^{1}$ Nozomi Ogawa, and Yasuo Mori ${ }^{1-3}$
}

\begin{abstract}
Significance: Environmental and endogenous reactive species such as reactive oxygen species (ROS), reactive nitrogen species (RNS), and other electrophiles are not only known to exert toxic effects on organisms, but are also emerging as molecules that mediate cell signaling responses. However, the mechanisms underlying this cellular redox signaling by reactive species remains largely uncharacterized. Recent Advances: $\mathrm{Ca}^{2+}$-permeable cation channels encoded by the transient receptor potential $(t r p)$ gene superfamily are characterized by a wide variety of activation triggers that act from outside and inside the cell. Recent studies have revealed that multiple TRP channels sense reactive species and induce diverse physiological and pathological responses, such as cell death, chemokine production, and pain transduction. TRP channels sense reactive species either indirectly through second messengers or directly via oxidative modification of cysteine residues. In this review, we describe the activation mechanisms and biological roles of redox-sensitive TRP channels, including TRPM2, TRPM7, TRPC5, TRPV1, and TRPA1. Critical Issues: The sensitivity of TRP channels to reactive species in vitro has been well characterized using molecular and pharmacological approaches. However, the precise activation mechanism(s) and in vivo function(s) of ROS/RNS-sensitive TRP channels remain elusive. Future Directions: Redox sensitivity of TRP channels has been shown to mediate previously unexplained biological phenomena and is involved in various pathologies. Understanding the physiological significance and activation mechanisms of TRP channel regulation by reactive species may lead to TRP channels becoming viable pharmacological targets, and modulators of these channels may offer therapeutic options for previously untreatable diseases. Antioxid. Redox Signal. 21, 971-986.
\end{abstract}

\section{Introduction}

$\mathbf{T}$ HE TERM "reactive oxygen species (ROS)" collectively describes not only the oxygen $\left(\mathrm{O}_{2}\right)$ radicals, but also some nonradical derivatives of $\mathrm{O}_{2}$, and includes the superoxide anion $\left(\mathrm{O}_{2}{ }^{--}\right)$, hydrogen peroxide $\left(\mathrm{H}_{2} \mathrm{O}_{2}\right)$ and the hydroxyl radical $\left({ }^{\circ} \mathrm{OH}\right)$ (45). Nitric oxide (NO) and peroxynitrite $\left(\mathrm{ONOO}^{-}\right)$are known as reactive nitrogen species (RNS) (45). Production of ROS occurs naturally during respiration through the mitochondrial electron transport chain (34). ROS and RNS are also enzymatically generated by the NOX family of NADPH oxidases and NO synthases, respectively $(2,34$, 79). Furthermore, ROS are generated after exposure to extracellular agents, ionizing radiation, cytotoxic drugs, and infectious agents $(68,110)$. Oxidative damage to DNA, lipids, and proteins causes cellular dysfunction and is a threat to the organism $(45,68)$. Organisms have developed defensive cellular responses and behavior to specifically detect and respond to oxidative stimuli $(45,68,110)$. The phrase "oxidative stress" refers to a state of imbalance between the production of ROS/RNS and the capacity of the antioxidant defense system (68). Excessive and/or a sustained increase in ROS production have been implicated in the pathogenesis of cancer, diabetes mellitus, atherosclerosis, neurodegenerative diseases, rheumatoid arthritis, ischemia/reperfusion injury, pulmonary hypertension, and other diseases $(18,34,150)$.

Apart from the role of ROS/RNS in disease, organisms have evolved to utilize ROS/RNS as signaling molecules for physiological functions. These include regulation of vascular tone, monitoring of oxygen tension to control ventilation and

\footnotetext{
${ }^{1}$ Department of Synthetic Chemistry and Biological Chemistry, Graduate School of Engineering, Kyoto University, Kyoto, Japan.

${ }^{2}$ Department of Technology and Ecology, Hall of Global Environmental Studies, Kyoto University, Kyoto, Japan.

${ }^{3}$ Core Research for Evolutional Science and Technology, Japan Science and Technology Agency, Tokyo, Japan.
} 
erythropoietin production, immune function, antimicrobial effects, and signal transduction $(18,34)$.

There are various proteins that detect the redox status of a cell. ROS activates transcription factors such as nuclear factor$\kappa \mathrm{B}(\mathrm{NF}-\kappa \mathrm{B})$ and activator protein-1 (34). A complex between Kelch-like ECH-associated protein-1 and nuclear factor (erythroid-derived-2)-like-2 detects ROS in mammals, and regulates responses that protect against environmental stress $(12,31)$. Myofilament proteins and some protein kinases are also modulated by ROS $(34,144)$. RNS also regulate the activity of a diverse array of proteins, including enzymes, protein kinases, phosphatases, transcription factors, and others $(51,149)$. Notably, a group of calcium ion channels were also discovered to detect the redox status of the cell and to mediate cellular responses (17).

TRP proteins are the products of trp genes, the first of which was discovered in Drosophila melanogaster (103). The term "TRP" is derived from "transient receptor potential," because the trp gene mutant photoreceptors fail to generate the $\mathrm{Ca}^{2+}$ dependent sustained phase of receptor potential and, therefore, fail to induce subsequent $\mathrm{Ca}^{2+}$-dependent adaptation to light. The currently identified mammalian TRP channels are divided into six subfamilies [canonical (C), vanilloid (V), melastatin (M), polycystic kidney disease $(\mathrm{P})$, mucolipin (ML), and ankyrin (A)] by the degree of homology of their protein sequences $(25,26)$ (Fig. 1). TRP channels have several common structural features: six transmembrane segments; a pore-forming region between the fifth and sixth transmembrane segments; cytoplasmic $\mathrm{N}$ - and C-terminal regions; and

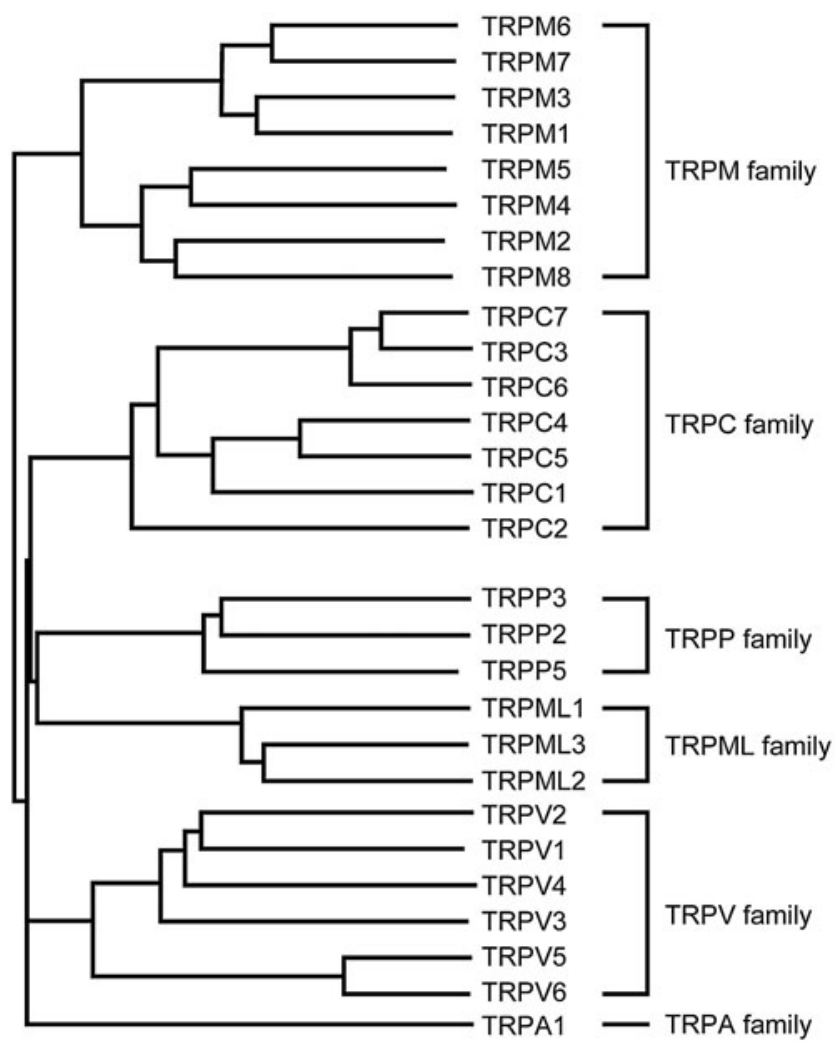

FIG. 1. Phylogenetic tree of TRP channels. Phylogenetic tree of mammalian TRP channels based on their homology. TRP, transient receptor potential. tetrameric subunit stoichiometry (Fig. 2). TRP proteins form cation channels that detect cellular stimuli and transduce them into electrical and chemical signals via changes in membrane potential and intracellular $\mathrm{Ca}^{2+}$ concentration $\left(\left[\mathrm{Ca}^{2+}\right]_{\mathrm{i}}\right)$, respectively. TRP channels are activated by (i.e., sense) diverse stimuli, including receptor stimulation, heat, osmotic pressure, mechanical stress, and environmental irritants from the extracellular and intracellular milieu $(25,42$, $116,171)$. The TRPC homologs are receptor-activated $\mathrm{Ca}^{2+}$ permeable cation channels that sense metabotropic changes after receptor stimulation, which activates and induces phospholipase C (PLC) to hydrolyze phosphatidylinositol4,5-bisphosphate $\left(\mathrm{PIP}_{2}\right)$ into inositol-1,4,5-trisphosphate and diacylglycerol $(115,169)$. TRPV Ca ${ }^{2+}$-permeable channels can be functionally defined as thermosensors (120). TRPV1, originally identified as the receptor for the vanilloid compound capsaicin, is responsive to heat $\left(>43^{\circ} \mathrm{C}\right)$, proton concentration $(\mathrm{pH}<5.6)$, the intrinsic ligand anandamide, and

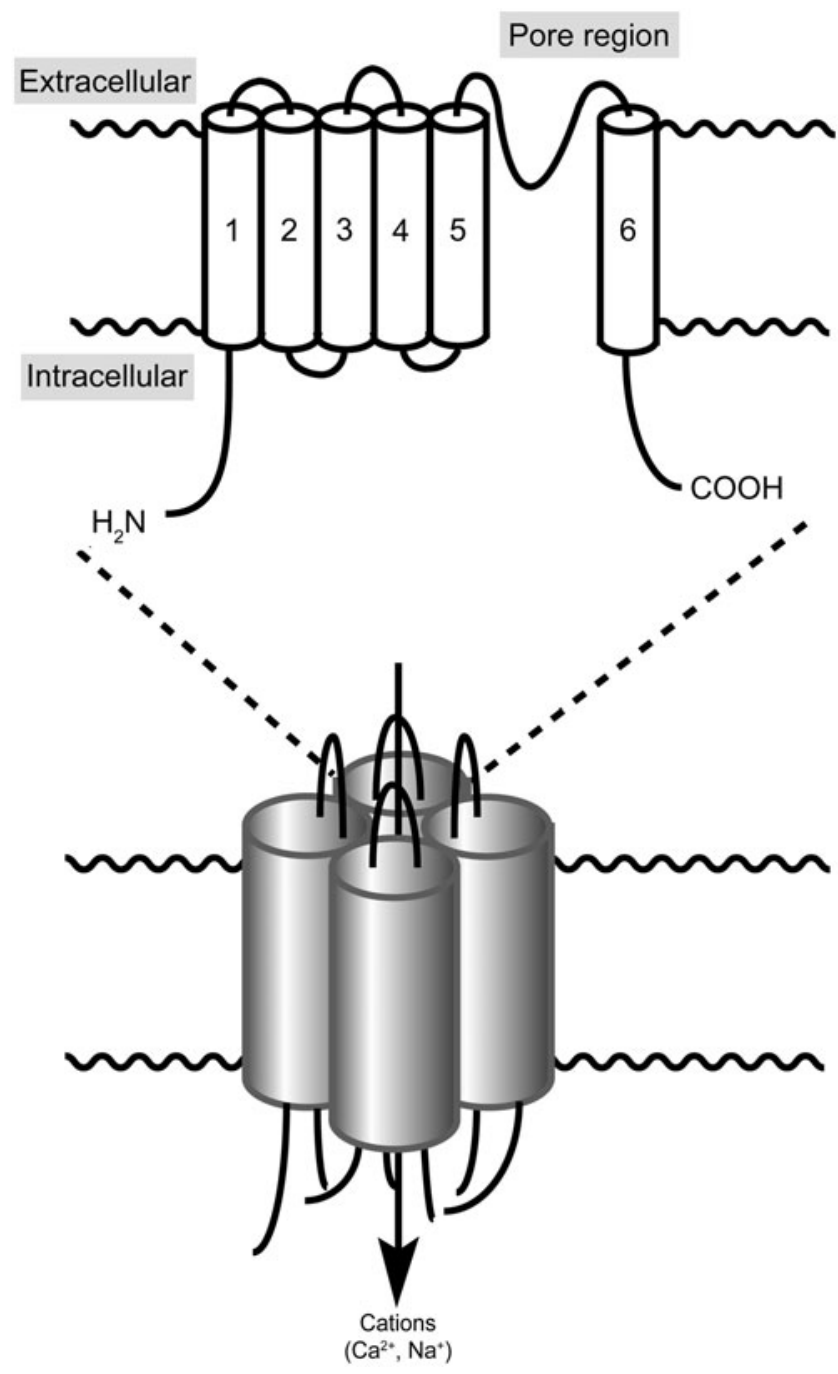

FIG. 2. Transmembrane topology of TRP channels. TRP channels have common structural features: six transmembrane segments, a pore-forming region between the fifth and sixth transmembrane segments, cytoplasmic N- and Cterminal regions, and tetrameric subunit stoichiometry. 
receptor-driven PLC activity (21, 24, 162, 190). High temperature also activates TRPV2, TRPV3, and TRPV4 (120). TRPV5 and TRPV6 are distinct from other TRPVs, because they are highly $\mathrm{Ca}^{2+}$-selective channels and are tightly regulated by $\left[\mathrm{Ca}^{2+}\right]_{\mathrm{i}}(113)$. The TRPM subfamily is named after melastatin (TRPM1), a tumor suppressor protein isolated in a screen for genes whose level of expression is inversely correlated with the severity of metastatic potential in a melanoma cell line (36). TRPM8 channels, in contrast to TRPV channels, are activated by low temperature and menthol $(95,122)$. The sole member of the TRPA subfamily, TRPA1, has a large $\mathrm{N}$ terminal domain with many predicted ankyrin repeats and is activated by environmental irritant compounds and noxious cold stimuli $(65,145)$.

Notably, a class of TRP channels has been found to be modulated by ROS/RNS and to control various cellular processes in response. TRPM2, the first identified ROSsensitive TRP channel, is activated by $\mathrm{H}_{2} \mathrm{O}_{2}$ (47). Accumulating evidence suggests that $\mathrm{H}_{2} \mathrm{O}_{2}$-activated $\mathrm{Ca}^{2+}$ influx through TRPM2 mediates several cellular responses, including cell death (47) and chemokine production in monocytes that aggravates inflammatory neutrophil infiltration (180). TRPM7 is activated by ROS/RNS and is an essential mediator of anoxic death (1). In addition to TRPM2 and TRPM7, certain members of the TRPC and TRPV subfamily, including TRPC5 and TRPV1, are activated by ROS and NO (183). Notably, the activation of TRPC5 and TRPV1 is through oxidative modification of the free sulfhydryl group of a cysteine residue (183). More recently, the activation of the TRPA1 channel has been shown to occur after oxidative cysteine modification by ROS and RNS (153). TRPA1 is also activated by environmental electrophiles and endogenous electrophilic products of oxidative stress $(4,53,88)$, and it is putatively involved in pain transduction and detection of the ROS microenvironment in the airway (11). This review explores the activation mechanisms and biological significance of these TRP channels in redox-related conditions.

\section{TRPM2}

\section{TRPM2: the first identified ROS-sensitive TRP channel}

The transcripts of TRPM2 (formerly designated TRPC7 and LTRPC2) were recognized to encode a protein product bearing homology to TRP proteins (106). Notably, we have demonstrated that TRPM2 is activated by $\mathrm{H}_{2} \mathrm{O}_{2}$ (47). The application of $\mathrm{H}_{2} \mathrm{O}_{2}$ induces TRPM2 currents and an increase in $\left[\mathrm{Ca}^{2+}\right]_{i}$ in TRPM2-expressing HEK cells and RIN-5F rat insulinoma cells. Subsequently, substantial evidence has accumulated demonstrating the activation of TRPM2 by $\mathrm{H}_{2} \mathrm{O}_{2}$ in various cell types, including TRPM2-transfected cells (175), microglia (74), hippocampal neurons (118), U937 human monocytes $(180,186)$, neutrophils $(54)$, pancreatic $\beta$-cells (80), and endothelial cells (49). The $\mathrm{H}_{2} \mathrm{O}_{2}$-induced $\mathrm{Ca}^{2+}$ influx through TRPM2 was enhanced under intracellular $\mathrm{Fe}^{2+}$ accumulated conditions and reduced by ${ }^{\circ} \mathrm{OH}$ scavengers or an iron chelator, suggesting that the intracellular ${ }^{\circ} \mathrm{OH}$ plays a key role in the activation (57). TRPM2 is also activated in response to the nitrosative stress-inducing donor $N$-methyl$N^{\prime}$-nitro- $N$-nitrosoguanidine (125).

Other studies have revealed that TRPM2 is a $\mathrm{Ca}^{2+}$. permeable nonselective cation channel that is specifically gated by adenosine diphosphoribose (ADPR) $(70,76,123,134)$ and adopts a swollen, bell-shaped tetrameric conformation (92). ADPR gating of TRPM2 is made possible by a C-terminal domain, designated the NUDT9-homology (NUDT9-H) domain, which is homologous to the NUDT9 ADPR pyrophosphatase that catabolizes the conversion of ADPR into adenosine monophosphate and ribose 5-phosphate (123). The residual enzymatic activity of the purified NUDT9-H domain of TRPM2 is lower than that of NUDT9, and the binding affinity of the NUDT9-H domain to ADPR seems to be more important for the gating process of TRPM2 (77, 123-125). In addition, $\mathrm{Ca}^{2+}$ is a modulator of TRPM2 $(28,94,143)$.

\section{Molecular mechanisms of TRPM2 activation by ROS}

In our experiments using the conventional whole-cell mode of patch clamp method, which perfuses cytoplasm with pipette solution, TRPM2 currents were not induced by $\mathrm{H}_{2} \mathrm{O}_{2}$, suggesting that intracellular mediators are necessary for $\mathrm{H}_{2} \mathrm{O}_{2}$-induced TRPM2 activation (47). Initially, we showed that nicotinamide adenine dinucleotide $\left(\mathrm{NAD}^{+}\right)$generated on ROS stimulation can directly induce the opening of TRPM2 (47). It is now believed that this opening is mainly mediated by conversion of $\mathrm{NAD}^{+}$to ADPR and by the production of ADPR from mitochondria (125). Cytosolic or mitochondrial overexpression of ADPR pyrophosphatase, which degrades ADPR, suppresses $\mathrm{H}_{2} \mathrm{O}_{2}$-induced $\mathrm{Ca}^{2+}$ responses, confirms the involvement of ADPR in $\mathrm{H}_{2} \mathrm{O}_{2}$-induced TRPM2 activation. ADPR can be also generated in the nucleus by a pathway involving poly(ADPR) polymerase-1 (PARP-1) (139), with a similar pathway putatively functioning in mitochondria (35). In response to DNA-strand breaks arising from oxidative damage, PARP-1 uses $\mathrm{NAD}^{+}$as a substrate to catalyze the successive transfer of several ADPR moieties to nuclear protein acceptors (139). The resulting polymer of ADPR can interact in a selective manner with a number of protein targets that are involved in the cellular response to DNA damage and DNA metabolism. Subsequently, free ADPR is generated after the degradation of poly(ADPR) by poly(ADPR) glycohydrolase (PARG). Thus, it is hypothesized that the free ADPR which activates TRPM2 is produced by the activation of PARP-1 and PARG. Corroborating this hypothesis, three structurally distinct PARP inhibitors suppress $\mathrm{H}_{2} \mathrm{O}_{2}$-induced activation of TRPM2 (39), but electrophysiological studies have shown that these PARP inhibitors have no effect on the activation of TRPM2 by ADPR itself. Thus, the PARP inhibitors should act upstream of TRPM2. In addition, it has been reported that the PARP-deficient DT40 lymphocytes constitutively expressing TRPM2 exhibit no $\mathrm{H}_{2} \mathrm{O}_{2}$-induced $\mathrm{Ca}^{2+}$ response (19). More support for this mechanism comes from the observation that PARP-1 and PARG control $\mathrm{H}_{2} \mathrm{O}_{2}$ -induced extracellular $\mathrm{Ca}^{2+}$ fluxes through TRPM2 in mouse embryonic fibroblasts (16). In inside-out patches from TRPM2expressing Xenopus oocytes, $\mathrm{H}_{2} \mathrm{O}_{2}$ failed to activate TRPM2 (163), suggesting that the $\mathrm{H}_{2} \mathrm{O}_{2}$ sensitivity of TRPM2 may be dependent on the production of ADPR from both the mitochondria and nucleus (Fig. 3).

Another potential source of free ADPR is the NAD ${ }^{+}$glycohydrolases, ADPR-producing ectoenzymes such as CD38 and CD157 localized on the plasma membrane (91). CD38 and CD157 are enzymes that generate ADPR from $\mathrm{NAD}^{+}$by their extracellular domains. CD38 could potentially contribute to the signaling events of TRPM2-mediated ion fluxes, although 
A

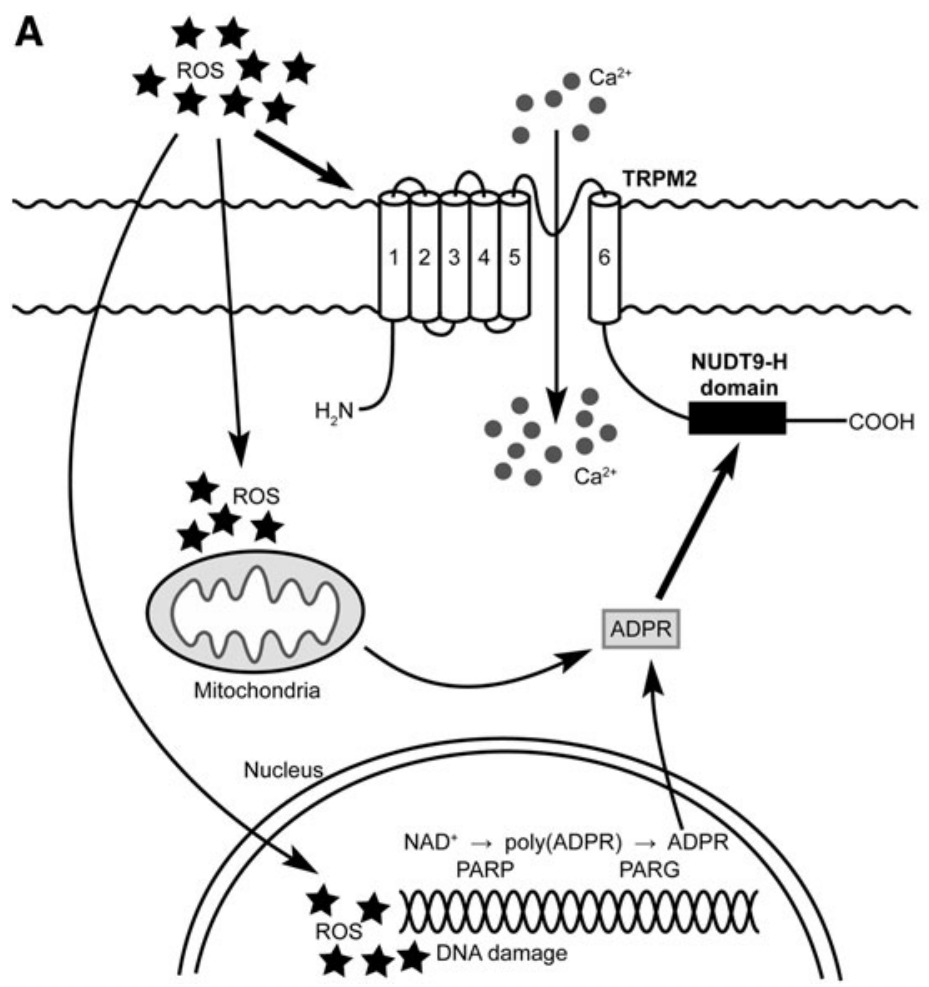

B

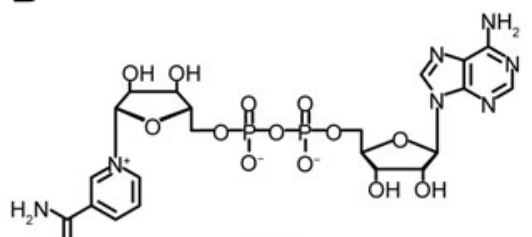

NAD*



ADPR

FIG. 3. Possible pathways for the activation of TRPM2 by ROS. (A) $\mathrm{H}_{2} \mathrm{O}_{2}$ mobilizes ADPR from the mitochondria and nucleus through PARP-1/PARG pathway, which then activates TRPM2. TRPM2 may also be gated directly by $\mathrm{H}_{2} \mathrm{O}_{2}$. (B) Chemical structures of $\mathrm{NAD}^{+}$and ADPR. ADPR, adenosine diphosphoribose; $\mathrm{H}_{2} \mathrm{O}_{2}$, hydrogen peroxide; ROS, reactive oxygen species; $\mathrm{NAD}^{+}$, nicotinamide adenine dinucleotide.

if and how ADPR generated extracellularly by CD38 enters the cell to reach the intracellular ADPR binding domain of TRPM2 has yet to be determined.

Contradicting the hypothesis that $\mathrm{H}_{2} \mathrm{O}_{2}$ activates TRPM2 indirectly through ADPR, lines of evidence suggest that TRPM2 can be gated directly by $\mathrm{H}_{2} \mathrm{O}_{2}$ (Fig. 3). For instance, a splice variant of TRPM2, a deletion mutant lacking amino acids 1292-1325 in the C-terminal of NUDT9-H domain and thus displaying decreased affinity for ADPR, is not activated by the intracellular application of ADPR, but responds to $\mathrm{H}_{2} \mathrm{O}_{2}$ (175). $\mathrm{H}_{2} \mathrm{O}_{2}$ also triggers single-channel activity in excised membrane patches of TRPM2-transfected $\mathrm{CHO}$ cells $(111,112)$. This suggests that $\mathrm{H}_{2} \mathrm{O}_{2}$ may activate TRPM2 through a mechanism independent of ADPR. It is suggested that $\mathrm{H}_{2} \mathrm{O}_{2}$ acts as a direct stimulus for TRPM2 activation, as it can initiate the release of ADPR from the mitochondria and at the same time, functions as a potentiating cofactor of ADPR (71). Methodological disparities such as culturing conditions, cell types, and drug application are likely responsible for the conflicting reports on TRPM2 activation by $\mathrm{H}_{2} \mathrm{O}_{2}$ (111). Further investigation is necessary to elucidate the ROSdependent activation mechanisms of TRPM2.

\section{Cell death and TRPM2}

On the basis of major association of ROS with cell death, we have previously proposed that TRPM2 mediates cell death (47). Since the first report of the involvement of TRPM2 in cell death, a substantial body of evidence obtained from various independent groups has supported this idea (97). TRPM2- expressing HEK cells are susceptible to cell death triggered by exposure to $\mathrm{H}_{2} \mathrm{O}_{2}$ through the elevation of $\left[\mathrm{Ca}^{2+}\right]_{i}(47)$. Coexpression of TRPM2 and the dominant-negative TRPM2 splice variant (in which the four C-terminal transmembrane domains and the entire $\mathrm{C}$ terminus are deleted) suppressed $\mathrm{H}_{2} \mathrm{O}_{2}$-induced $\mathrm{Ca}^{2+}$ influx through TRPM2, reduced susceptibility to cell death, and blocked the onset of apoptosis in HEK cells (185). The role of endogenous TRPM2 in $\mathrm{H}_{2} \mathrm{O}_{2-}$ induced cell death was revealed in various cell types, including cultured striatal cells (40), cultured cerebral cortical neurons (67), myocytes (182), RIN-5F insulinoma cells (47), U937 monocytic cells (186), and an endothelial cell line (147). A TRPM2-specific antisense oligonucleotide significantly suppressed $\mathrm{Ca}^{2+}$ influx and cell death induced by $\mathrm{H}_{2} \mathrm{O}_{2}$ in RIN-5F cells (47). Interestingly, PARP inhibitors protect rat striatal cells from $\mathrm{H}_{2} \mathrm{O}_{2}$-induced cell death (40), while PARP-1 and PARG were found to control $\mathrm{Ca}^{2+}$ fluxes through TRPM2 in a cell death signaling pathway induced by $\mathrm{H}_{2} \mathrm{O}_{2}$ in mouse embryonic fibroblasts (16). In addition, Lange et al. reported that TRPM2 functions as a $\mathrm{Ca}^{2+}$-release channel activated by intracellular ADPR in a lysosomal compartment in addition to its role as a plasma membrane channel, and both functions of TRPM2 were shown to be critically linked to $\mathrm{H}_{2} \mathrm{O}_{2}$-induced pancreatic $\beta$-cell death using short-interfering RNA (siRNA) and Trpm 2 knockout (KO) mice techniques (80).

Consistent with the hypothesis that activation of TRPM2 results in cell death, TRPM2 appears to regulate caspase signaling. Most apoptotic pathways converge on the family of caspases (15). Caspase-8 plays a central role in the extrinsic cell death pathways involving transmembrane receptor- 
mediated interactions, whereas caspase- 9 is an important component in the intrinsic cell death pathway. Caspases-6, -7, and -3 are downstream of caspase- 8 and caspase- 9 , with caspase-3 ultimately executing cell apoptosis. In the U937 cell line, in which $\mathrm{H}_{2} \mathrm{O}_{2}$ activates caspases-8, $-9,-3$ and -7 and dramatically up-regulates the cleavage of PARP protein, down-regulation of endogenous TRPM2 by RNA interference inhibited the rise in $\left[\mathrm{Ca}^{2+}\right]_{i}$, enhanced cell viability, and reduced the numbers of apoptotic cells after exposure to $\mathrm{H}_{2} \mathrm{O}_{2}$ (186). Other groups also showed that TRPM2 activity stimulated the activation of caspases- $8,-9,-6$, and $-3(16,147)$. These results link TRPM2 to the activation of caspases in $\mathrm{H}_{2} \mathrm{O}_{2}$ induced cell death (151).

Amyloid $\beta$-peptide $(\mathrm{A} \beta)$ is the main component of the plaques that characterize Alzheimer's disease (AD) and may induce neuronal death through mechanisms which involve oxidative stress (181). Accumulating evidence suggests that a failure of $\mathrm{Ca}^{2+}$ homeostasis plays a critical role in the neuropathology of $\mathrm{AD}$. Incubation of cells in $\mathrm{Ca}^{2+}$-free medium attenuated the direct neurotoxicity of $\mathrm{A} \beta$ and limited their vulnerability to excitotoxicity, suggesting the involvement of $\mathrm{Ca}^{2+}$ influx in these processes (93). Fonfria et al. have shown that the application of $\mathrm{A} \beta$ led to the generation of ROS in cultures of rat striatal neurons, and used data from siRNA experiments targeting TRPM2 to assert that the activation of TRPM2, functionally expressed in primary cultures of rat striatum, contributes to $\mathrm{A} \beta$ - and $\mathrm{H}_{2} \mathrm{O}_{2}$-induced striatal cell death (40). Thus, TRPM2 activity likely contributes to neuronal cell death in AD.

\section{Inflammation and TRPM2}

At sites of inflammation, ROS are secreted from immunocytes and epithelial cells $(34,50)$, such that a large amount of ROS is present at these sites. Intracellular $\mathrm{Ca}^{2+}$ also plays important signaling roles in immunocytes, and increases in $\left[\mathrm{Ca}^{2+}\right]_{i}$ are important for the production of certain cytokines, including interleukin-2 in T cells (38) and CXCL8 in U937 human monocytic cells $(170,176)$. CXCL8 is a key chemotactic cytokine mediating the recruitment of neutrophils migrating into inflammation sites (87). In human monocytes, production of CXCL8 is induced by $\mathrm{H}_{2} \mathrm{O}_{2}$ (66) via extracellular signal-regulated kinase (Erk)-activated NF- $\kappa \mathrm{B}$ (184). Until recently, despite evidence implicating $\mathrm{H}_{2} \mathrm{O}_{2}$ and $\mathrm{Ca}^{2+}$ as important regulatory factors in CXCL8 production in monocytes, the molecular entities and signaling mechanisms that link $\mathrm{H}_{2} \mathrm{O}_{2}, \mathrm{Ca}^{2+}$, and CXCL8 production remained unclear.

In U937 monocytes, $\mathrm{H}_{2} \mathrm{O}_{2}$-induced increases in $\left[\mathrm{Ca}^{2+}\right]_{\mathrm{i}}$ and the production of CXCL8 were significantly suppressed by TRPM2-specific siRNA (180). We found that $\mathrm{H}_{2} \mathrm{O}_{2}$-induced nuclear translocation of the NF- $\kappa$ B subunit RelA was positively regulated by Erk-mediated phosphorylation of $\mathrm{I} \kappa \mathrm{B}$ kinase- $\beta$ (IKK- $\beta$ ). In addition, upstream of Erk activation, TRPM2 activation by $\mathrm{H}_{2} \mathrm{O}_{2}$ results in $\mathrm{Ca}^{2+}$ influx and consequent autophosphorylation of $\mathrm{Ca}^{2+}$-sensitive proline-rich tyrosine kinase 2 (Pyk2), which amplifies Erk activation via Ras GTPase. The activation of this Pyk2/Erk/NF- $\kappa$ B pathway in response to $\mathrm{H}_{2} \mathrm{O}_{2}$ was demonstrated in wild-type monocytes, but was impaired in Trpm $2 \mathrm{KO}$ monocytes. Thus, $\mathrm{H}_{2} \mathrm{O}_{2}$ mediated $\mathrm{Ca}^{2+}$ influx via TRPM2 triggers Pyk2/Ras signaling, which amplifies downstream Erk activation leading to the nuclear translocation of NF- $\kappa \mathrm{B}$ and the production CXCL2, the murine functional homologue of human CXCL8 (Fig. 4).

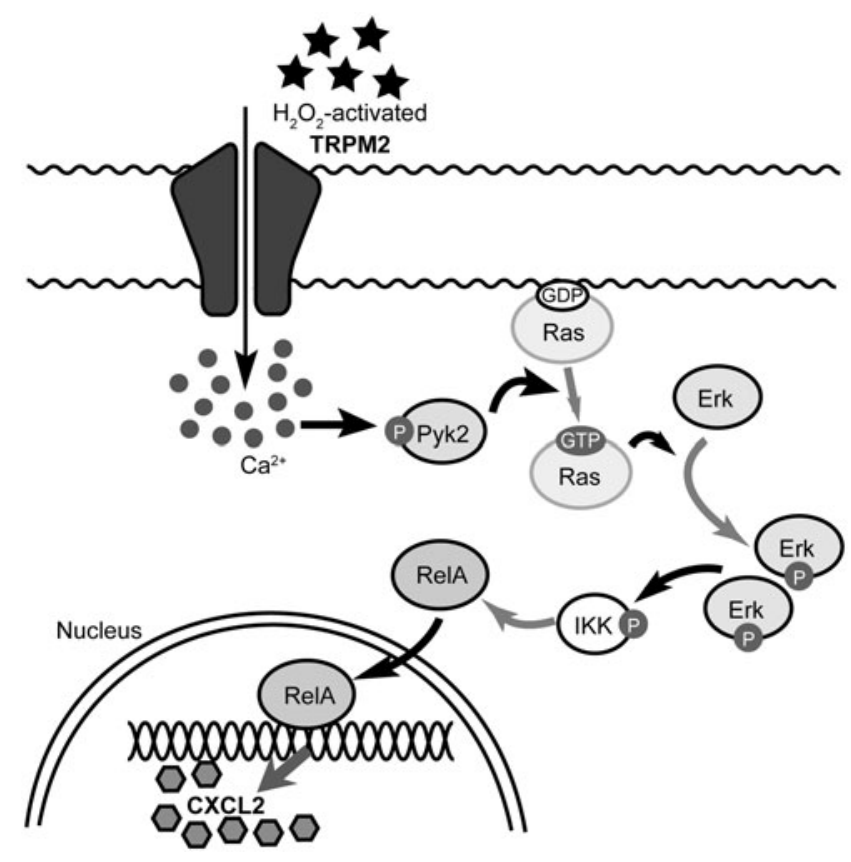

FIG. 4. TRPM2 activation by $\mathrm{H}_{2} \mathrm{O}_{2}$ induces chemokine production. In monocytes, $\mathrm{Ca}^{2+}$ influx via $\mathrm{H}_{2} \mathrm{O}_{2}$-activated TRPM2 triggers Pyk2 phosphorylation, which amplifies Erk activation in an Ras-dependent manner. The amplified Erk activates transcription of the $\mathrm{C} x \mathrm{cl} 2$ gene by inducing nuclear translocation of the NF- $\kappa$ B subunit RelA.

We characterized the Trpm $2 \mathrm{KO}$ mouse phenotype in a dextran sulfate sodium (DSS)-induced model of ulcerative colitis that was associated with ROS production $(72,180)$. As expected, the Trpm $2 \mathrm{KO}$ mice were largely protected from DSS-mediated colitis. Histological assessments revealed profound inflammation and tissue destruction characterized by mucosal ulceration, serosa destruction, epithelial injury, and inflammatory cell infiltration in the colon of wild-type mice. In Trpm $2 \mathrm{KO}$ mice, the severity of the DSS-induced colitis was dramatically reduced, although epithelial injury was still observed in the colon. Expression of CXCL2 and the number of recruited neutrophils were severely diminished in the colon tissue of DSS-treated Trpm $2 \mathrm{KO}$ mice. The number of macrophages and other inflammatory cells infiltrating into the colon was indistinguishable between wild-type and Trpm2 KO mice. These results suggest that the diminished expression of CXCL2 in monocytes/macrophages induced by ROS contributes to the paucity of neutrophil accumulation in the colon of DSS-treated Trpm2 KO mice. Thus, TRPM2-mediated chemokine production in monocytes/macrophages is an important mechanism in the progressive severity of DSSinduced ulcerative colitis (Fig. 5). Recently, Di et al. also showed that neither $\mathrm{H}_{2} \mathrm{O}_{2}$ nor lipopolysaccharide (LPS)induced ROS were able to induce inward currents or increases in $\left[\mathrm{Ca}^{2+}\right]_{\mathrm{i}}$ in Trpm $2 \mathrm{KO}$ bone marrow-derived macrophages (32). We previously demonstrated that CXCL2 production induced by $\mathrm{H}_{2} \mathrm{O}_{2}$ and LPS is diminished in Trpm $2 \mathrm{KO}$ monocytes (180). Conversely, Di et al. showed that LPS challenge caused greater release of CXCL2 and inflammatory responses in lung in Trpm $2 \mathrm{KO}$ mice than in wild-type mice, suggesting that TRPM2 activation by ROS may reduce rather than enhance the production of CXCL2 and the inflammatory 
FIG. 5. ROS-induced TRPM2dependent chemokine production in monocytes/macrophages aggravates inflammatory neutrophil infiltration. ROS, including $\mathrm{H}_{2} \mathrm{O}_{2}$, generated and released from various cells at inflamed sites, activate TRPM2 channels in monocytes/macrophages. CXCL2-induced neutrophil accumulation at the inflamed sites plays an important role in the pathogenesis of ulcerative colitis. response (32). In conclusion, since the roles of ROS-sensitive TRPM2 in inflammatory diseases are controversial, it will be important to delineate and clarify these differences in the pathological phenotype of Trpm $2 \mathrm{KO}$ mice.

\section{TRPM7}

\section{Anoxic cell death and TRPM7}

TRPM7, a divalent cation channel permeable to $\mathrm{Mg}^{2+}$ and $\mathrm{Ca}^{2+}$ and containing a C-terminal serine/threonine kinase domain, is a widely expressed member of the TRPM ion channel subfamily $(102,105,131,138)$. TRPM7 currents are inhibited by $\mathrm{Mg}^{2+}$ and $\mathrm{Zn}^{2+}$, and activated by low levels of $\operatorname{MgATP}(73,105)$. Targeted deletion of TRPM7 in DT-40 B cells is lethal. These cells exhibited $\mathrm{Mg}^{2+}$ deficiency, growth arrest, and death within $24 \mathrm{~h}$ unless rescued by increased levels of extracellular $\mathrm{Mg}^{2+}$ (105). These studies, along with others in which TRPM7 expression was down-regulated $(46,48)$, demonstrate that precise regulation of TRPM7 expression is necessary for cell viability and growth.

ROS and RNS can serve as activators of cation conductance through TRPM7, contributing to anoxic neuronal death (1). It has been proposed that during oxygen and glucose deprivation of primary cortical neurons, a $\mathrm{Ca}^{2+}$-permeable nonse- lective cation conductance mediated by TRPM7 is activated by ROS/RNS and is primarily responsible for neuronal death. This is supported by the observation that ROS/RNS are able to enhance the TRPM7-mediated inward current in TRPM7transfected HEK293 cells. In addition, in primary neurons, it appears that the electrophysiological properties of currents activated by oxygen- and glucose deprivation, including currents enhanced by low $\mathrm{Mg}^{2+}$ and inhibited by high $\mathrm{Mg}^{2+}$, are characteristic of TRPM7 and are not shared by TRPM2. Suppression of TRPM7 expression in primary cortical neurons blocked TRPM7 currents, $\mathrm{Ca}^{2+}$ influx, and ROS production, protecting cells from anoxic cell death. However, siRNA targeted against TRPM7 also reduced TRPM2 levels (1), suggesting that expression of TRPM2 and TRPM7 are codependent. In summary, although it is difficult to definitively distinguish the roles of TRPM2 and TRPM7 in anoxic injury, both TRPM7 and TRPM2 channels appear to be important in oxidative stress-induced cell death (100). Interestingly, the proposed role of TRPM7 in anoxic cell death was confirmed in vivo (146). The suppression of TRPM7 in rats by intrahippocampal injections of viral vectors bearing small hairpin RNA specific for TRPM7 made neurons resistant to ischemic death and preserved neuronal function and performance for hippocampus-dependent learning tasks after brain 
ischemia. This suggests that TRPM7 can be selectively targeted to prevent ischemic brain damage.

\section{TRPC5}

\section{Direct modulation of TRPC5 via NO oxidative modification of cysteine residues}

TRPC5 was originally cloned from mouse brain and functionally identified as a receptor-activated $\mathrm{Ca}^{2+}$-permeable cation channel linked to PLC $(117,126)$. Although it is still controversial whether depletion of $\mathrm{Ca}^{2+}$ stores can activate TRPC5, a number of proteins and factors have been shown to act as direct triggers and modulators of TRPC 5 channel activation $(63,104)$. For example, binding of intracellular $\mathrm{Ca}^{2+}$ and calmodulin has been implicated in TRPC 5 activation and modulation $(14,43,119,140)$, while membrane polyphosphoinositides such as $\mathrm{PIP}_{2}$ exert both stimulatory and inhibitory effects in regulating TRPC5 channel activity (165).

We have previously demonstrated that TRPC 5 is directly activated by $\mathrm{H}_{2} \mathrm{O}_{2}$ and the $\mathrm{NO}$ donor, $\mathrm{S}$-nitroso- $\mathrm{N}$-acetyl-DLpenicillamine, via cysteine modification $(154,183)$. In endothelial cells, native TRPC5 is likely to be activated by NO generated by endothelial-type NO synthase (183). Redox modification of cysteine residue sulfhydryl groups has emerged as an important elementary step in the signal transduction cascades that underlie many physiological responses $(12,135)$. NO-activated TRPC5 channels were significantly but not entirely suppressed by ascorbate, which reduces $S$ nitrosothiols (but not disulfides) to thiols. However, dithiothreitol (DTT), which reduces both $S$-nitrosothiols and disulfides to thiols, fully suppressed NO-activated TRPC5 channel activity. Thus, both nitrosylation and disulfide bond formation are likely to be involved in NO-induced TRPC5 activation. Our functional assays employing cysteine mutants have shown that cysteine residues accessible from the cytoplasm (namely Cys553 and nearby Cys558 on the N-terminal side of the putative pore-forming region between the fifth and sixth transmembrane domains) are essential for NO-induced mouse TRPC5 activation (Fig. 6). In an S-nitrosylation assay (59), S-nitrosylation was abolished by mutation of Cys553, but was unaffected by mutation of Cys558. Our data suggest that the TRPC5 channel is opened via S-nitrosylation of Cys553 and a subsequent nucleophilic attack on nitrosylated Cys553 by the free sulfhydryl group of Cys558 to form a disulfide bond that stabilizes the open state. However, the NO sensitivity of TRPC5 channels was refuted by another group (177). It has been reported that TRPC5 may form a disulfide bridge between Cys553 and Cys558, and is activated by the reducing agent DTT and by extracellular reduced thioredoxin, both of which cleave the disulfide bridge (179). Thus, it is possible that the sensitivity of TRPC 5 to both NO and redox status is dependent on culturing conditions, drug application, cell density during measurements, and/or other experimental conditions, which may affect the redox sensitivity of TRPC5, levels of antioxidants, or other molecular and cellular redox states.

\section{TRPV1}

\section{Modulation of TRPV1 by ROS/RNS via oxidative modification of cysteine residues}

The nonselective cation channel TRPV1 is activated by various noxious stimuli, including heat $\left(>43^{\circ} \mathrm{C}\right)(21)$, acidic
$\mathrm{pH}$ (162), and environmental irritants and endogenous algesic substances, including capsaicin (21), camphor (178), 12hydroperoxyeicosatetraenoic acid $(56,141)$, bradykinin (127), and anandamide (190). TRPV1 is expressed in primary afferent nociceptors of dorsal root ganglia, trigeminal ganglia, nodose ganglia $(21,162)$, the central nervous system, and nonneuronal tissues $(22,98)$. Importantly, TRPV1 can detect and integrate sub-threshold stimuli owing to its sensitivity to multimodal stimuli. For example, capsaicin- and heatinduced activation of TRPV1 is enhanced by mild acidosis and inflammatory agents involved in the activation of PLC signaling $(3,24,61,127,162)$.

In addition to these stimuli, TRPV1 was also found to be sensitized and activated by oxidative stress. We found that TRPV1 channels heterologously expressed in HEK cells are activated by both $\mathrm{H}_{2} \mathrm{O}_{2}$ and $\mathrm{NO}$ (183). An alignment of aminoacid sequences surrounding Cys553 and Cys558 of TRPC5 (which confer its redox sensitivity) with counterpart sequences in TRPV1 shows cysteine residues conserved on the N-terminal side of the putative pore-forming region (Cys616 and Cys621 in rat) located between the fifth and sixth transmembrane domains. Mutation of these cysteines reduces the $\mathrm{Ca}^{2+}$ influx induced by $\mathrm{H}_{2} \mathrm{O}_{2}$ and $\mathrm{NO}$, suggesting that TRPV1 redox sensitivity is conferred by these cysteine residues (183). However, this view has been challenged by Miyamoto et al., who reported that the double cysteine mutant C616W:C621S shows normal NO-induced calcium responses when normalized against capsaicin responses (101). Other groups have reported that both oxidizing agents (such as $\mathrm{H}_{2} \mathrm{O}_{2}$, diamide, and chloramine-T) and reducing agents (i.e., DTT) sensitize rat TRPV1 and amplify its response to heat and capsaicin, with Cys621 identified as a key residue in its sensitization by a reducing agent $(148,172)$. In avian TRPV1, which is capsaicin insensitive, sensitivity to oxidation was attributed to multiple cysteine residues on the $\mathrm{N}$ - and C-terminal domains (23). It is generally believed that formation of a disulfide bond(s) is the molecular mechanism underpinning oxidative sensitization/ activation. A biochemical study has demonstrated that oxidation of TRPV1 induces C-terminal dimerization via disulfide bond formation (173), but there is currently no direct evidence corroborating this hypothesis in vivo.

Recently, it has been suggested that the activity of neuronal NO synthase contributes to the activation of TRPV1. Ito et al. reported that mechanical overload-induced muscle hypertrophy is triggered by the activation of TRPV1 localized in sarcoplasmic reticulum by $\mathrm{NO}$ and $\mathrm{ONOO}^{-}$, which are downstream products of neuronal NO synthase (58).

TRPV1 is not activated by all oxidizing agents. Intriguingly, oxidation of TRPV1 by some oxidizing agents, such as the antiseptic thimerosal or copper-o-phenanthroline, suppresses TRPV1 activation $(64,164)$. The effect of thimerosal was blocked by the application of DTT and by point mutation of Cys621, suggesting that oxidative modification of cysteine residues was involved in the mechanism of suppression (64). In contrast, the effect of copper-o-phenanthroline seems to be independent of cysteine residues: mutation (individually and collectively) of three putative cysteine residues located on the extracellular membrane leaflet could not preclude copper-ophenanthroline from effectively blocking TRPV1 activation by heat, protons, and capsaicin (164).

TRPV1 also shows sensitivity to pungent compounds from onion and garlic, such as allicin (89), through covalent 
A

TRPC5

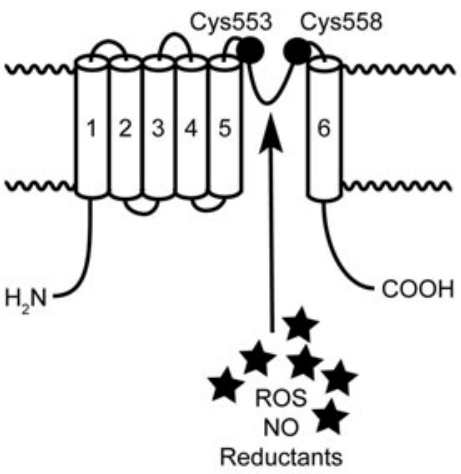

TRPV1

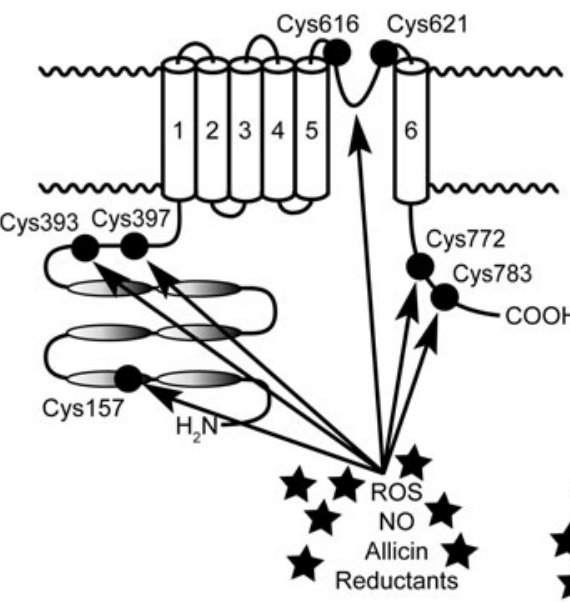

TRPA1

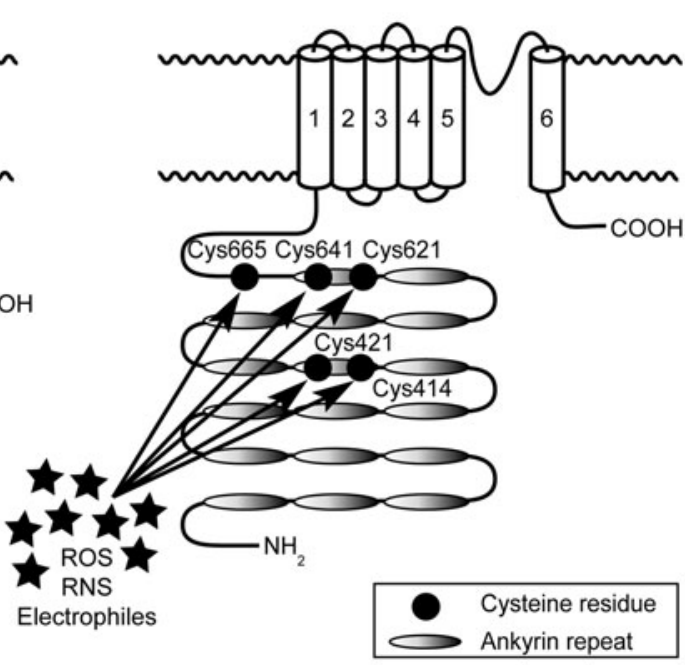

B

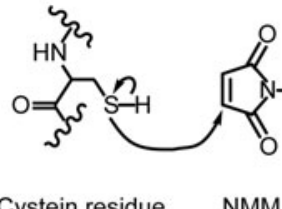

C<smiles>C=C=NCC=C</smiles>

AITC<smiles>C=CCSS(=O)CC=C</smiles>

Allicin<smiles>O=C/C=C/c1ccccc1</smiles>

Cinnamaldehyde<smiles>C=CC=O</smiles>

Acrolein<smiles>CCCCCC(O)/C=C/C=O</smiles>

4-HNE

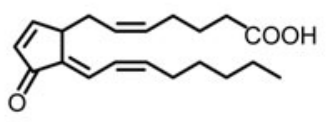

$15 d-P G J_{2}$

FIG. 6. Redox regulation of TRPC5, TRPV1, and TRPA1 through direct modification of cysteine residues. (A) ROS/RNS, electrophiles, and reductants regulate TRPC5, TRPV1, and TRPA1. TRPC5 is regulated through the modification of specific cysteine residues in the pore region (mouse Cys553 and Cys558). TRPV1 is regulated through the modification of specific cysteine residues in the pore region (rat Cys616 and Cys621) and the cytoplasmic N- and C-terminal region (rat Cys157, chicken Cys393, Cys397, Cys772, and Cys783) (23). TRPA1 is regulated through the modification of multiple cysteine residues in the cytoplasmic N-terminal region (human Cys414, Cys421, Cys621, Cys641, and Cys665) (41). (B) The chemical mechanism underlying the action of NMM, one of $\alpha, \beta$-unsaturated aldehydes, on cysteine sulfhydryls $(9,53)$. (C) Chemical structures of major agonists of TRPA1 $(8,62,88,153)$.

modification of a single cysteine residue (Cys157) located in the N-terminal region, which contains six ankyrin repeats $(84$, 133). This target cysteine is different from those for oxidizing and reducing agents described earlier, suggesting that TRPV1 harbors multiple modifiable cysteines which could mediate channel activation in an agent-specific manner (Fig. 6).

Research on TRPV1 sensitivity to oxidants is so far limited to molecular and pharmacological characterization. The molecular mechanism of oxidation-induced TRPV1 activation appears to involve cysteine modification, but further studies are necessary to prove the involvement of disulfide bonds and to delineate the complex and nonuniform activation effects of different oxidizing and reducing agents. More importantly, the physiological and pathological roles of TRPV1 sensitivity to the redox state in vivo have yet to be characterized. However, tissue injury and inflammation results in abundant production of ROS/RNS, which may enhance the pain response through the sensitization of TRPV1 (101). U1timately, the use of knock-in mutants of Cys621 or other oxidation-insensitive cysteines will be necessary to explore the physiological role of TRPV1 redox sensitivity.

\section{TRPA1}

\section{Modulation of TRPA1 by ROS/RNS and various electrophiles via oxidative modification of cysteine residues}

TRPA1 is the only member of the TRPA sub-branch of the TRP gene superfamily in mammals that is characterized by a large number (between 12 and 17) of $\mathrm{N}$-terminal ankyrin repeats $(29,41,114)$. TRPA1 was first cloned from a fibroblast cell line (60), and its expression in vivo is largely restricted to a subset of nociceptive C-fiber nerves, including the somatosensory and vagal nerves $(7,107,109,145)$. TRPA1 was initially identified as a cold-sensitive ion channel in a small subset of sensory neurons (145), but subsequent pharmacological experiments have revealed it is also the sensory neuronal receptor for exogenous pungent compounds such as allyl isothiocyanate (AITC) from mustard oil and wasabi (7, 65), cinnamaldehyde from cinnamon (7), and allicin from onion and garlic (89). TRPA1 is also activated by $\mathrm{Ca}^{2+}$ (33, $189)$, receptor stimulation $(7,30,137,174)$, cannabinoids (65), caffeine (108), nicotine (155), and heavy metals $(44,55)$. 
AITC, allicin, and cinnamaldehyde are isothiocyanate, thiosulfinate, and $\alpha, \beta$-unsaturated aldehyde compounds, respectively. These compounds are susceptible to attack by the sulfhydryl groups of cysteine residues via nucleophilic substitution or Michael addition $(53,135)$. Related exogenous compounds such as acrolein, formalin, $N$-methyl maleimide, and tear gases also activate TRPA1 $(7,8,10,53,81,88,96,128$, $132,187,188)$. Systematic mutation of TRPA1 cysteine residues identified three neighboring cysteines within the cytoplasmic N-terminus on human TRPA1 (Cys621, Cys641, and Cys665), simultaneous mutation of which decreases channel activation by several cysteine-modifying reagents (53). Mass spectrometry and site-directed mutagenesis independently implicated three cysteines in mouse TRPA1 (Cys415, Cys422, and Cys622, conserved in the human homolog as Cys414, Cys421, and Cys621) as the target sites for AITC and cinnamaldehyde (88) (Fig. 6). Thus, TRPA1 is a redox-mediated receptor for environmental electrophilic compounds.

We and others have demonstrated that TRPA1 is also modified via oxidative cysteine modification by ROS and RNS. TRPA1 is activated by ROS/RNS such as hypochlorite $\left(\mathrm{OCl}^{-}\right)(11), \mathrm{H}_{2} \mathrm{O}_{2}(4,11,136,153)$, ozone $\left(\mathrm{O}_{3}\right)(159)$, $\mathrm{NO}(101$, $136,153), \mathrm{ONOO}^{-}(136)$, and the ROS generated by ultraviolet light (52). In these reports, functional characterization of site-directed cysteine mutants of TRPA1 collectively demonstrated that modifications of cytoplasmic N-terminal-specific cysteine residues (Csy421, Cys621, Cya641, and Cys665 in human TRPA1) are the primary targets of these reactive species.

ROS and RNS can react with unsaturated fatty acids, causing production of highly reactive electrophilic compounds, including 4-hydroxynonenal (4-HNE), 4-hydroxyhexenal (4-HHE), 4-oxononenal (4-ONE), and nitrooleic acid (9$\left.\mathrm{OA}-\mathrm{NO}_{2}\right)(62,82,167)$. It has been reported that 4-HNE, 4$\mathrm{HHE}$, 4-ONE, and 9-OA- $\mathrm{NO}_{2}$ activate TRPA1 channels through oxidative modification of the same cysteine residues previously identified by $(4,53,156,158,166)$. In addition to lipid peroxidation products, 15 -deoxy- $\Delta^{12,14}$-prostaglandin $\mathrm{J}_{2}$ $\left(15 \mathrm{~d}-\mathrm{PGJ}_{2}\right)$, an endogenously generated product of the cyclooxygenase pathway with a highly reactive structure that contains $\alpha, \beta$-unsaturated aldehyde moieties, can also react covalently via a Michael addition reaction with nucleophiles (168). $15 \mathrm{~d}_{-} \mathrm{PGJ} \mathrm{J}_{2}$ also activates TRPA1 in heterologous systems and endogenous TRPA1 in dissociated sensory neurons $(4,90$, $153,161)$. Functional characterization of site-directed cysteine mutants of TRPA1 in combination with labeling experiments using biotinylated $15 \mathrm{~d}-\mathrm{PGJ}_{2}$ demonstrated that modification of cytoplasmic N-terminal Cys621 is responsible for the incorporation of $15 \mathrm{~d}-\mathrm{PG} \mathrm{J}_{2}$ into TRPA1 (153). Taken together, we can surmise that endogenous electrophilic products activate TRPA1 channels.

It has been demonstrated that TRP channels such as TRPC5, TRPV1, and TRPA1 are sensitive to cysteine oxidation. In order to quantitate their cysteine oxidation sensitivity, we have systematically compared the responses of redoxsensitive TRP channels with a congeneric series of reactive disulfides, which show different electron acceptor (oxidation) capacity indicated as redox potential obtained using rotating disc electrode voltammetry (152). Strikingly, among the TRPs tested, only TRPA1 responded to those reactive disulfides with the least oxidative capacity, suggesting that TRPA1 possesses the highest oxidation sensitivity (Fig. 7).

\section{TRPA1 in detecting noxious stimuli and the airway ROS microenvironment}

The detection of noxious stimuli elicits nociceptive pain. Similar to capsaicin, the application of AITC produces an acute noxious response, followed by neurogenic inflammation and robust hypersensitivity to thermal and mechanical stimuli (8). Behavioral responses such as licking and flinching were abolished in Trpa1 KO mice, whereas wild-type mice showed characteristically robust behavior $(8,78)$. Unlike wildtype mice, Trpa1 KO mice also showed no hypersensitivity to thermal and mechanical stimuli after mustard-oil treatment (8). TRPA1 mediates pain responses to not only AITC but also formalin and other compounds $(37,96,121)$. Trpa1 $\mathrm{KO}$ mice have been used to show that an intraplantar injection of $\mathrm{H}_{2} \mathrm{O}_{2}, 15 \mathrm{~d}-\mathrm{PGJ}_{2}$, or 4-HNE induces pain sensation by activating TRPA1 $(4,11,27,166)$. Thus, TRPA1 is a redoxmediated nociceptive receptor for exogenous and endogenous electrophiles.
FIG. 7. Quantification of oxidation sensitivity of TRP channels. The threshold redox potentials for activation of respective TRP channels by reactive disulfides (152).

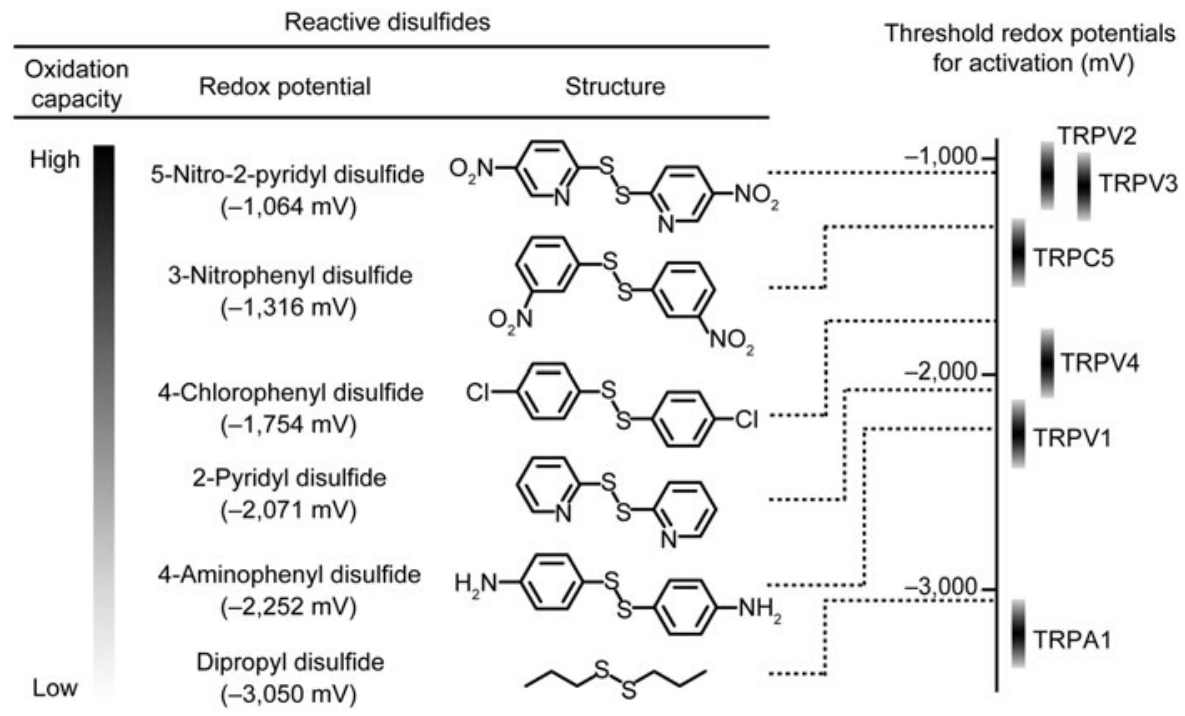


The respiratory tract can be subjected to substantial oxidative stress, both in the form of inhaled irritants and pollutants and during chronic inflammatory diseases $(9,160)$. Bronchopulmonary $\mathrm{C}$-fibers of vagal nerves innervate the airways and play a critical role in the detection of the airway microenvironment (75). AITC, cinnamaldehyde, and $\mathrm{O}_{3}$ activate dissociated vagal neurons and bronchopulmonary C-fibers in a TRPA1-dependent manner $(109,158,159)$. Recently, our systematic evaluation of the oxidation sensitivity of TRP cation channels using reactive disulfides with different electrophilicity revealed the capability of TRPA1 to sense $\mathrm{O}_{2}$ levels in bronchopulmonary C-fibers (152). Strikingly, in vivo inhalation of $\mathrm{H}_{2} \mathrm{O}_{2}$ and $\mathrm{OCl}^{-}$given as an aerosol evoked a decrease in respiratory rate and an increase in end expiratory pause, but these responses were abolished in Trpa1 KO mice (11). In addition, exposing the airways to AITC or toluene diisocyanate evokes a decrease in respiratory rate in wild-type but not Trpa1 KO mice (157). In guinea pigs, several electrophiles (e.g., cinnamaldehyde and acrolein) cause a cough that could be inhibited by a TRPA1 antagonist $(6,13)$. Taken together, these findings implicate TRPA1 expressed in vagal afferents as being at the frontline of the defense against pulmonary ROS and electrophilic compound challenges (152), with its activation leading to modulation of protective reflexes.

The role of ROS-modulated TRPA1 signaling in the airway afferents has been studied in relation to cigarette smoke. In rats, cigarette smoke-induced neuronal responses in capsaicin-sensitive vagal and superior laryngeal afferents were mediated through an ROS-dependent mechanism involving the activation of TRPA1 and TRPV1 receptors $(83,85$, 130). Andrè et al. showed that cigarette smoke-induced neurogenic airway inflammatory responses, which consist mainly of bronchoconstriction and plasma protein extravasation, may be the result of TRPA1 activation by crotonaldehyde and acrolein, two $\alpha, \beta$-unsaturated aldehydes present in cigarette smoke $(5,142)$. Another important role for TRPA1 has been suggested from a mouse model of allergic asthma (20). However, both cigarette smoke and inflammation can modulate airway nociceptor function independently of ROS, so further analyses are necessary to determine whether ROSmediated TRPA1 activation induced by smoke and inflammation is physiologically relevant (160).

\section{Concluding Remarks}

A subclass of TRP channels is activated by reactive oxygen and nitrogen species and other electrophiles either directly through oxidative cysteine modification or indirectly via the downstream products of ROS generation. TRP channel cysteine residues susceptible to oxidation may have specific activation ranges, and it is conceivable that these modified cysteines control the activity of TRP channels under widely differing cellular redox conditions in order to gate the channel appropriately. Although many of the reports cited in this article name cysteine oxidation as the activation mechanism, it is almost certain that other factors also play a role. Future studies should investigate not only cysteine but also methionine and lysine residues as potential oxidation targets, because these are also prone to modification by endogenous oxidants. Indeed, methionine in TRPM2 is thought to play a role in sensing $\mathrm{H}_{2} \mathrm{O}_{2}(69)$, and a lysine residue in TRPA1 was identified as a target of electrophiles (53). For TRPC5 and TRPV1, both cysteine oxidation and reduction play roles in channel sensitization $(172,179)$. This sensitization function of reductive agents is an exciting phenomenon that is currently unexplored.

Redox-sensitive TRP channels are ubiquitous, widely distributed, and participate in ROS-dependent cellular functions, including cell death, chemokine production, and ROS detection, but novel roles are emerging for redox-sensitive TRP channels in ischemia/reperfusion, neurodegeneration, mental illness, vascular hyperpermeability, and itch sensation (49, $54,86,99,111,129)$. Considering the ubiquitous nature of TRP channels and ROS/RNS production, it is conceivable that TRP channel redox sensitivity may also participate in other unidentified biological phenomena. Thus, characterization of the in vivo functions of ROS-sensitive TRP channels in physiological and pathological conditions is a fertile field for exploration.

Redox sensitivity of TRP channels is now known to mediate previously unexplained biological phenomena, and is involved in various pathological states. A better understanding of the activation mechanisms and physiological significance of TRP channel regulation by reactive species may position TRP channels as significant pharmacological targets, which may realize the prospect of discovery of highly novel therapeutics for the management of previously untreatable diseases.

\section{Acknowledgments}

The authors thank N. Takahashi and T. Numata for helpful discussions.

\section{References}

1. Aarts M, Iihara K, Wei WL, Xiong ZG, Arundine M, Cerwinski W, MacDonald JF, and Tymianski M. A key role for TRPM7 channels in anoxic neuronal death. Cell 115: 863877, 2003.

2. Alderton WK, Cooper CE, and Knowles RG. Nitric oxide synthases: structure, function and inhibition. Biochem J 357: 593-615, 2001.

3. Amadesi S, Nie J, Vergnolle N, Cottrell GS, Grady EF, Trevisani M, Manni C, Geppetti P, McRoberts JA, Ennes H, Davis JB, Mayer EA, and Bunnett NW. Protease-activated receptor 2 sensitizes the capsaicin receptor transient receptor potential vanilloid receptor 1 to induce hyperalgesia. J Neurosci 24: 4300-4312, 2004.

4. Andersson DA, Gentry C, Moss S, and Bevan S. Transient receptor potential $\mathrm{A} 1$ is a sensory receptor for multiple products of oxidative stress. J Neurosci 28: 2485-2494, 2008.

5. Andrè E, Campi B, Materazzi S, Trevisani M, Amadesi $S$, Massi D, Creminon C, Vaksman N, Nassini R, Civelli M, Baraldi PG, Poole DP, Bunnett NW, Geppetti P, and Patacchini R. Cigarette smoke-induced neurogenic inflammation is mediated by $\alpha, \beta$-unsaturated aldehydes and the TRPA1 receptor in rodents. J Clin Invest 118: 2574-2582, 2008.

6. Andrè E, Gatti R, Trevisani M, Preti D, Baraldi PG, Patacchini $R$, and Geppetti P. Transient receptor potential ankyrin receptor 1 is a novel target for pro-tussive agents. Br J Pharmacol 158: 1621-1628, 2009.

7. Bandell M, Story GM, Hwang SW, Viswanath V, Eid SR, Petrus MJ, Earley TJ, and Patapoutian A. Noxious cold ion 
channel TRPA1 is activated by pungent compounds and bradykinin. Neuron 41: 849-857, 2004.

8. Bautista DM, Jordt SE, Nikai T, Tsuruda PR, Read AJ, Poblete J, Yamoah EN, Basbaum AI, and Julius D. TRPA1 mediates the inflammatory actions of environmental irritants and proalgesic agents. Cell 124: 1269-1282, 2006.

9. Bessac BF and Jordt SE. Breathtaking TRP channels: TRPA1 and TRPV1 in airway chemosensation and reflex control. Physiology 23: 360-370, 2008.

10. Bessac BF, Sivula M, von Hehn CA, Caceres AI, Escalera J, and Jordt SE. Transient receptor potential ankyrin 1 antagonists block the noxious effects of toxic industrial isocyanates and tear gases. FASEB J 23: 1102-1114, 2009.

11. Bessac BF, Sivula M, von Hehn CA, Escalera J, Cohn L, and Jordt SE. TRPA1 is a major oxidant sensor in murine airway sensory neurons. J Clin Invest 118: 1899-1910, 2008.

12. Bindoli A and Rigobello MP. Principles in redox signaling: from chemistry to functional significance. Antioxid Redox Signal 18: 1557-1593, 2013.

13. Birrell MA, Belvisi MG, Grace M, Sadofsky L, Faruqi S, Hele DJ, Maher SA, Freund-Michel V, and Morice AH. TRPA1 agonists evoke coughing in guinea pig and human volunteers. Am J Respir Crit Care Med 180: 1042-1047, 2009.

14. Blair NT, Kaczmarek JS, and Clapham DE. Intracellular calcium strongly potentiates agonist-activated TRPC5 channels. J Gen Physiol 133: 525-546, 2009.

15. Blankenberg FG and Norfray JF. Multimodality molecular imaging of apoptosis in oncology. Am J Roentgenol 197: 308-317, 2011.

16. Blenn C, Wyrsch P, Bader J, Bollhalder M, and Althaus FR. Poly(ADP-ribose)glycohydrolase is an upstream regulator of $\mathrm{Ca}^{2+}$ fluxes in oxidative cell death. Cell Mol Life Sci 68: 1455-1466, 2011.

17. Bogeski I, Kappl R, Kummerow C, Gulaboski R, Hoth M, and Niemeyer BA. Redox regulation of calcium ion channels: chemical and physiological aspects. Cell Calcium 50: 407-423, 2011.

18. Brieger K, Schiavone S, Miller FJ, Jr., and Krause KH. Reactive oxygen species: from health to disease. Swiss Med Wkly 142: w13659, 2012.

19. Buelow B, Song Y, and Scharenberg AM. The poly(ADPribose) polymerase PARP-1 is required for oxidative stressinduced TRPM2 activation in lymphocytes. J Biol Chem 283: 24571-24583, 2008.

20. Caceres AI, Brackmann M, Elia MD, Bessac BF, del Camino D, D'Amours M, Witek JS, Fanger CM, Chong JA, Hayward NJ, Homer RJ, Cohn L, Huang X, Moran MM, and Jordt SE. A sensory neuronal ion channel essential for airway inflammation and hyperreactivity in asthma. Proc Natl Acad Sci U S A 106: 9099-9104, 2009.

21. Caterina MJ, Schumacher MA, Tominaga M, Rosen TA, Levine JD, and Julius D. The capsaicin receptor: a heatactivated ion channel in the pain pathway. Nature 389: 816824, 1997.

22. Cavanaugh DJ, Chesler AT, Jackson AC, Sigal YM, Yamanaka H, Grant R, O'Donnell D, Nicoll RA, Shah NM, Julius D, and Basbaum AI. Trpv1 reporter mice reveal highly restricted brain distribution and functional expression in arteriolar smooth muscle cells. J Neurosci 31: 5067-5077, 2011.

23. Chuang $\mathrm{HH}$ and Lin S. Oxidative challenges sensitize the capsaicin receptor by covalent cysteine modification. Proc Natl Acad Sci U S A 106: 20097-20102, 2009.

24. Chuang HH, Prescott ED, Kong H, Shields S, Jordt SE, Basbaum AI, Chao MV, and Julius D. Bradykinin and nerve growth factor release the capsaicin receptor from PtdIns $(4,5) \mathrm{P}_{2}$-mediated inhibition. Nature 411: 957-962, 2001.

25. Clapham DE. TRP channels as cellular sensors. Nature 426 : 517-524, 2003.

26. Clapham DE, Julius D, Montell C, and Schultz G. International Union of Pharmacology. XLIX. Nomenclature and structure-function relationships of transient receptor potential channels. Pharmacol Rev 57: 427-450, 2005.

27. Cruz-Orengo L, Dhaka A, Heuermann RJ, Young TJ, Montana MC, Cavanaugh EJ, Kim D, and Story GM. Cutaneous nociception evoked by 15-delta PGJ2 via activation of ion channel TRPA1. Mol Pain 4: 30, 2008.

28. Csanády L and Töröcsik B. Four $\mathrm{Ca}^{2+}$ ions activate TRPM2 channels by binding in deep crevices near the pore but intracellularly of the gate. J Gen Physiol 133: 189-203, 2009.

29. Cvetkov TL, Huynh KW, Cohen MR, and MoiseenkovaBell VY. Molecular architecture and subunit organization of TRPA1 ion channel revealed by electron microscopy. J Biol Chem 286: 38168-38176, 2011.

30. Dai Y, Wang S, Tominaga M, Yamamoto S, Fukuoka T, Higashi T, Kobayashi K, Obata K, Yamanaka H, and Noguchi K. Sensitization of TRPA1 by PAR2 contributes to the sensation of inflammatory pain. J Clin Invest 117: 19791987, 2007.

31. D'Autréaux B and Toledano MB. ROS as signalling molecules: mechanisms that generate specificity in ROS homeostasis. Nat Rev Mol Cell Biol 8: 813-824, 2007.

32. Di AK, Gao XP, Qian F, Kawamura T, Han J, Hecquet C, Ye $\mathrm{RD}$, Vogel SM, and Malik AB. The redox-sensitive cation channel TRPM2 modulates phagocyte ROS production and inflammation. Nat Immunol 13: 29-34, 2012.

33. Doerner JF, Gisselmann G, Hatt H, and Wetzel CH. Transient receptor potential channel A1 is directly gated by calcium ions. J Biol Chem 282: 13180-13189, 2007.

34. Dröge W. Free radicals in the physiological control of cell function. Physiol Rev 82: 47-95, 2002.

35. Du LN, Zhang XP, Han YY, Burke NA, Kochanek PM, Watkins SC, Graham SH, Carcillo JA, Szabó C, and Clark RS. Intra-mitochondrial poly(ADP-ribosylation) contributes to $\mathrm{NAD}^{+}$depletion and cell death induced by oxidative stress. J Biol Chem 278: 18426-18433, 2003.

36. Duncan LM, Deeds J, Hunter J, Shao J, Holmgren LM, Woolf EA, Tepper RI, and Shyjan AW. Down-regulation of the novel gene melastatin correlates with potential for melanoma metastasis. Cancer Res 58: 1515-1520, 1998.

37. Escalera J, von Hehn CA, Bessac BF, Sivula M, and Jordt SE. TRPA1 mediates the noxious effects of natural sesquiterpene deterrents. J Biol Chem 283: 24136-24144, 2008.

38. Feske S, Giltnane J, Dolmetsch R, Staudt LM, and Rao A. Gene regulation mediated by calcium signals in $\mathrm{T}$ lymphocytes. Nat Immunol 2: 316-324, 2001.

39. Fonfria E, Marshall IC, Benham CD, Boyfield I, Brown JD, Hill K, Hughes JP, Skaper SD, and McNulty S. TRPM2 channel opening in response to oxidative stress is dependent on activation of poly(ADP-ribose) polymerase. $\mathrm{Br} \mathrm{J}$ Pharmacol 143: 186-192, 2004.

40. Fonfria E, Marshall IC, Boyfield I, Skaper SD, Hughes JP, Owen DE, Zhang W, Miller BA, Benham CD, and McNulty $\mathrm{S}$. Amyloid $\beta$-peptide(1-42) and hydrogen peroxideinduced toxicity are mediated by TRPM2 in rat primary striatal cultures. J Neurochem 95: 715-723, 2005.

41. Gaudet R. A primer on ankyrin repeat function in TRP channels and beyond. Mol BioSyst 4: 372-379, 2008. 
42. Gees M, Colsoul B, and Nilius B. The role of transient receptor potential cation channels in $\mathrm{Ca}^{2+}$ signaling. Cold Spring Harb Perspect Biol 2: a003962, 2010.

43. Gross SA, Guzmán GA, Wissenbach U, Philipp SE, Zhu MX, Bruns D, and Cavalié A. TRPC5 is a $\mathrm{Ca}^{2+}$-activated channel functionally coupled to $\mathrm{Ca}^{2+}$-selective ion channels. J Biol Chem 284: 34423-34432, 2009.

44. Gu Q and Lin RL. Heavy metals zinc, cadmium, and copper stimulate pulmonary sensory neurons via direct activation of TRPA1. J Appl Physiol 108: 891-897, 2010.

45. Halliwell B. Oxidative stress and neurodegeneration: where are we now? J Neurochem 97: 1634-1658, 2006.

46. Hanano T, Hara Y, Shi J, Morita H, Umebayashi C, Mori E, Sumimoto H, Ito $\mathrm{Y}$, Mori $\mathrm{Y}$, and Inoue R. Involvement of TRPM7 in cell growth as a spontaneously activated $\mathrm{Ca}^{2+}$ entry pathway in human retinoblastoma cells. J Pharmacol Sci 95: 403-419, 2004.

47. Hara $Y$, Wakamori $M$, Ishii $M$, Maeno E, Nishida $M$, Yoshida T, Yamada H, Shimizu S, Mori E, Kudoh J, Shimizu N, Kurose H, Okada Y, Imoto K, and Mori Y. LTRPC2 $\mathrm{Ca}^{2+}$-permeable channel activated by changes in redox status confers susceptibility to cell death. Mol Cell 9: 163173, 2002.

48. He Y, Yao GY, Savoia C, and Touyz RM. Transient receptor potential melastatin 7 ion channels regulate magnesium homeostasis in vascular smooth muscle cells: role of angiotensin II. Circ Res 96: 207-215, 2005.

49. Hecquet CM, Ahmmed GU, Vogel SM, and Malik AB. Role of TRPM2 channel in mediating $\mathrm{H}_{2} \mathrm{O}_{2}$-induced $\mathrm{Ca}^{2+}$ entry and endothelial hyperpermeability. Circ Res 102: 347-355, 2008.

50. Henricks PA and Nijkamp FP. Reactive oxygen species as mediators in asthma. Pulm Pharmacol Ther 14: 409-421, 2001.

51. Hess DT, Matsumoto A, Kim SO, Marshall HE, and Stamler JS. Protein S-nitrosylation: purview and parameters. Nat Rev Mol Cell Biol 6: 150-166, 2005.

52. Hill $\mathrm{K}$ and Schaefer $\mathrm{M}$. Ultraviolet light and photosensitising agents activate TRPA1 via generation of oxidative stress. Cell Calcium 45: 155-164, 2009.

53. Hinman A, Chuang HH, Bautista DM, and Julius D. TRP channel activation by reversible covalent modification. Proc Natl Acad Sci U S A 103: 19564-19568, 2006.

54. Hiroi T, Wajima T, Negoro T, Ishii M, Nakano $Y$, Kiuchi $Y$, Mori Y, and Shimizu S. Neutrophil TRPM2 channels are implicated in the exacerbation of myocardial ischaemia/ reperfusion injury. Cardiovasc Res 97: 271-281, 2013.

55. Hu HZ, Bandell M, Petrus MJ, Zhu MX, and Patapoutian A. Zinc activates damage-sensing TRPA1 ion channels. Nat Chem Biol 5: 183-190, 2009.

56. Hwang SW, Cho H, Kwak J, Lee SY, Kang CJ, Jung J, Cho S, Min KH, Suh YG, Kim D, and Oh U. Direct activation of capsaicin receptors by products of lipoxygenases: endogenous capsaicin-like substances. Proc Natl Acad Sci U S A 97: 6155-6160, 2000.

57. Ishii M, Shimizu S, Hara Y, Hagiwara T, Miyazaki A, Mori $\mathrm{Y}$, and Kiuchi $\mathrm{Y}$. Intracellular-produced hydroxyl radical mediates $\mathrm{H}_{2} \mathrm{O}_{2}$-induced $\mathrm{Ca}^{2+}$ influx and cell death in rat $\beta$-cell line RIN-5F. Cell Calcium 39: 487-494, 2006.

58. Ito N, Ruegg UT, Kudo A, Miyagoe-Suzuki Y, and Takeda S. Activation of calcium signaling through Trpv1 by nNOS and peroxynitrite as a key trigger of skeletal muscle hypertrophy. Nat Med 19: 101-106, 2013.

59. Jaffrey SR, Erdjument-Bromage H, Ferris CD, Tempst $P$, and Snyder SH. Protein S-nitrosylation: a physiological signal for neuronal nitric oxide. Nat Cell Biol 3: 193-197, 2001.

60. Jaquemar D, Schenker T, and Trueb B. An ankyrin-like protein with transmembrane domains is specifically lost after oncogenic transformation of human fibroblasts. J Biol Chem 274: 7325-7333, 1999.

61. Ji RR, Samad TA, Jin SX, Schmoll R, and Woolf CJ. p38 MAPK activation by NGF in primary sensory neurons after inflammation increases TRPV1 levels and maintains heat hyperalgesia. Neuron 36: 57-68, 2002.

62. Jian W, Lee SH, Mesaros C, Oe T, Elipe MV, and Blair IA. A novel 4-oxo-2(E)-nonenal-derived endogenous thiadiazabicyclo glutathione adduct formed during cellular oxidative stress. Chem Res Toxicol 20: 1008-1018, 2007.

63. Jiang LH, Gamper N, and Beech DJ. Properties and therapeutic potential of transient receptor potential channels with putative roles in adversity: focus on TRPC5, TRPM2 and TRPA1. Curr Drug Targets 12: 724-736, 2011.

64. Jin Y, Kim DK, Khil LY, Oh U, Kim J, and Kwak J. Thimerosal decreases TRPV1 activity by oxidation of extracellular sulfhydryl residues. Neurosci Lett 369: 250-255, 2004.

65. Jordt SE, Bautista DM, Chuang HH, McKemy DD, Zygmunt PM, Högestätt ED, Meng ID, and Julius D. Mustard oils and cannabinoids excite sensory nerve fibres through the TRP channel ANKTM1. Nature 427: 260-265, 2004.

66. Josse C, Boelaert JR, Best-Belpomme M, and Piette J. Importance of post-transcriptional regulation of chemokine genes by oxidative stress. Biochem J 360: 321-333, 2001.

67. Kaneko S, Kawakami S, Hara Y, Wakamori M, Itoh E, Minami T, Takada Y, Kume T, Katsuki H, Mori Y, and Akaike A. A critical role of TRPM2 in neuronal cell death by hydrogen peroxide. J Pharmacol Sci 101: 66-76, 2006.

68. Karihtala P and Soini Y. Reactive oxygen species and antioxidant mechanisms in human tissues and their relation to malignancies. APMIS 115: 81-103, 2007.

69. Kashio M, Sokabe T, Shintaku K, Uematsu T, Fukuta N, Kobayashi N, Mori Y, and Tominaga M. Redox signalmediated sensitization of transient receptor potential melastatin 2 (TRPM2) to temperature affects macrophage functions. Proc Natl Acad Sci U S A 109: 6745-6750, 2012.

70. Knowles H, Li Y, and Perraud AL. The TRPM2 ion channel, an oxidative stress and metabolic sensor regulating innate immunity and inflammation. Immunol Res 55: 241-248, 2013.

71. Kolisek M, Beck A, Fleig A, and Penner R. Cyclic ADPribose and hydrogen peroxide synergize with ADP-ribose in the activation of TRPM2 channels. Mol Cell 18: 61-69, 2005.

72. Korenaga D, Takesue F, Kido K, Yasuda M, Inutsuka S, Honda $\mathrm{M}$, and Nagahama S. Impaired antioxidant defense system of colonic tissue and cancer development in dextran sulfate sodium-induced colitis in mice. J Surg Res 102: 144149, 2002.

73. Kozak JA and Cahalan MD. MIC channels are inhibited by internal divalent cations but not ATP. Biophys J 84: 922-927, 2003.

74. Kraft R, Grimm C, Grosse K, Hoffmann A, Sauerbruch S, Kettenmann H, Schultz G, and Harteneck C. Hydrogen peroxide and ADP-ribose induce TRPM2-mediated calcium influx and cation currents in microglia. Am J Physiol Cell Physiol 286: C129-C137, 2004.

75. Kubin L, Alheid GF, Zuperku EJ, and McCrimmon DR. Central pathways of pulmonary and lower airway vagal afferents. J Appl Physiol 101: 618-627, 2006. 
76. Kühn FJ, Heiner I, and Lückhoff A. TRPM2: a calcium influx pathway regulated by oxidative stress and the novel second messenger ADP-ribose. Pflugers Arch 451: 212-219, 2005.

77. Kühn FJ and Lückhoff A. Sites of the NUDT9-H domain critical for ADP-ribose activation of the cation channel TRPM2. J Biol Chem 279: 46431-46437, 2004.

78. Kwan KY, Allchorne AJ, Vollrath MA, Christensen AP, Zhang DS, Woolf CJ, and Corey DP. TRPA1 contributes to cold, mechanical, and chemical nociception but is not essential for hair-cell transduction. Neuron 50: 277-289, 2006.

79. Lambeth JD. Nox enzymes and the biology of reactive oxygen. Nat Rev Immunol 4: 181-189, 2004.

80. Lange I, Yamamoto S, Partida-Sanchez S, Mori Y, Fleig A, and Penner R. TRPM2 functions as a lysosomal $\mathrm{Ca}^{2+}$ release channel in $\beta$ cells. Sci Signal 2, 2009.

81. Leamy AW, Shukla P, McAlexander MA, Carr MJ, and Ghatta S. Curcumin ((E,E)-1,7-bis(4-hydroxy-3-methoxyphenyl)-1,6-heptadiene-3,5-dione) activates and desensitizes the nociceptor ion channel TRPA1. Neurosci Lett 503: 157-162, 2011.

82. Lee SH and Blair IA. Characterization of 4-oxo-2-nonenal as a novel product of lipid peroxidation. Chem Res Toxicol 13: 698-702, 2000.

83. Lin YS, Hsu CC, Bien MY, Hsu HC, Weng HT, and Kou YR. Activations of TRPA1 and P $2 \times$ receptors are important in ROS-mediated stimulation of capsaicin-sensitive lung vagal afferents by cigarette smoke in rats. J Appl Physiol 108: 1293-1303, 2010.

84. Lishko PV, Procko E, Jin X, Phelps CB, and Gaudet R. The ankyrin repeats of TRPV1 bind multiple ligands and modulate channel sensitivity. Neuron 54: 905-918, 2007.

85. Liu BY, Tsai TL, Ho CY, Lu SH, Lai CJ, and Kou YR. Role of TRPA1 and TRPV1 in the ROS-dependent sensory irritation of superior laryngeal capsaicin-sensitive afferents by cigarette smoke in anesthetized rats. Pulm Pharmacol Ther 26: 364-372, 2013.

86. Liu T and Ji RR. Oxidative stress induces itch via activation of transient receptor potential subtype ankyrin 1 in mice. Neurosci Bull 28: 145-154, 2012.

87. Luster AD. Chemokines-chemotactic cytokines that mediate inflammation. N Engl J Med 338: 436-445, 1998.

88. Macpherson LJ, Dubin AE, Evans MJ, Marr F, Schultz PG, Cravatt BF, and Patapoutian A. Noxious compounds activate TRPA1 ion channels through covalent modification of cysteines. Nature 445: 541-545, 2007.

89. Macpherson LJ, Geierstanger BH, Viswanath V, Bandell M, Eid SR, Hwang S, and Patapoutian A. The pungency of garlic: activation of TRPA1 and TRPV1 in response to allicin. Curr Biol 15: 929-934, 2005.

90. Maher M, Ao H, Banke T, Nasser N, Wu NT, Breitenbucher JG, Chaplan SR, and Wickenden AD. Activation of TRPA1 by farnesyl thiosalicylic acid. Mol Pharmacol 73: 1225-1234, 2008.

91. Malavasi F, Deaglio S, Funaro A, Ferrero E, Horenstein AL, Ortolan E, Vaisitti T, and Aydin S. Evolution and function of the ADP ribosyl cyclase/CD38 gene family in physiology and pathology. Physiol Rev 88: 841-886, 2008.

92. Maruyama Y, Ogura T, Mio K, Kiyonaka S, Kato K, Mori Y, and Sato $\mathrm{C}$. Three-dimensional reconstruction using transmission electron microscopy reveals a swollen, bell-shaped structure of transient receptor potential melastatin type 2 cation channel. J Biol Chem 282: 36961-36970, 2007.

93. Mattson MP, Barger SW, Cheng B, Lieberburg I, Smithswintosky VL, and Rydel RE. $\beta$-Amyloid precursor protein metabolites and loss of neuronal $\mathrm{Ca}^{2+}$ homeostasis in Alzheimer's-disease. Trends Neurosci 16: 409-414, 1993.

94. McHugh D, Flemming R, Xu SZ, Perraud AL, and Beech DJ. Critical intracellular $\mathrm{Ca}^{2+}$ dependence of transient receptor potential melastatin 2 (TRPM2) cation channel activation. J Biol Chem 278: 11002-11006, 2003.

95. McKemy DD, Neuhausser WM, and Julius D. Identification of a cold receptor reveals a general role for TRP channels in thermosensation. Nature 416: 52-58, 2002.

96. McNamara CR, Mandel-Brehm J, Bautista DM, Siemens J, Deranian KL, Zhao M, Hayward NJ, Chong JA, Julius D, Moran MM, and Fanger CM. TRPA1 mediates formalininduced pain. Proc Natl Acad Sci U S A 104: 13525-13530, 2007.

97. McNulty $S$ and Fonfria E. The role of TRPM channels in cell death. Pflugers Arch 451: 235-242, 2005.

98. Mezey É, Tóth ZE, Cortright DN, Arzubi MK, Krause JE, Elde R, Guo A, Blumberg PM, and Szallasi A. Distribution of mRNA for vanilloid receptor subtype 1 (VR1), and VR1like immunoreactivity, in the central nervous system of the rat and human. Proc Natl Acad Sci U S A 97: 3655-3660, 2000.

99. Miller BA, Wang J, Hirschler-Laszkiewicz I, Gao E, Song J, Zhang XQ, Koch WJ, Madesh M, Mallilankaraman K, Gu T, Chen SJ, Keefer K, Conrad K, Feldman AM, and Cheung JY. The second member of transient receptor potentialmelastatin channel family protects hearts from ischemiareperfusion injury. Am J Physiol Heart Circ Physiol 304: H1010-H1022, 2013.

100. Miller BA and Zhang WY. TRP channels as mediators of oxidative stress. In: Transient Receptor Potential Channels, edited by Islam MS. CA: Springer Netherlands, 2011, pp. 531-544.

101. Miyamoto T, Dubin AE, Petrus MJ, and Patapoutian A. TRPV1 and TRPA1 mediate peripheral nitric oxide-induced nociception in mice. PLoS One 4: e7596, 2009.

102. Monteilh-Zoller MK, Hermosura MC, Nadler MJ, Scharenberg AM, Penner R, and Fleig A. TRPM7 provides an ion channel mechanism for cellular entry of trace metal ions. J Gen Physiol 121: 49-60, 2003.

103. Montell C and Rubin GM. Molecular characterization of the Drosophila trp locus: a putative integral membrane protein required for phototransduction. Neuron 2: 1313-1323, 1989.

104. Mori Y, Kajimoto T, Nakao A, Takahashi N, and Kiyonaka S. Receptor signaling integration by TRP channelsomes. In: Transient Receptor Potential Channels, edited by Islam MS. CA: Springer Netherlands, 2011, pp. 373-389.

105. Nadler MJ, Hermosura MC, Inabe K, Perraud AL, Zhu Q, Stokes AJ, Kurosaki T, Kinet JP, Penner R, Scharenberg AM, and Fleig A. LTRPC7 is a Mg.ATP-regulated divalent cation channel required for cell viability. Nature 411: 590595, 2001.

106. Nagamine K, Kudoh J, Minoshima S, Kawasaki K, Asakawa S, Ito F, and Shimizu N. Molecular cloning of a novel putative $\mathrm{Ca}^{2+}$ channel protein (TRPC7) highly expressed in brain. Genomics 54: 124-131, 1998.

107. Nagata K, Duggan A, Kumar G, and Garcia-Añoveros J. Nociceptor and hair cell transducer properties of TRPA1, a channel for pain and hearing. J Neurosci 25: 4052-4061, 2005.

108. Nagatomo K and Kubo Y. Caffeine activates mouse TRPA1 channels but suppresses human TRPA1 channels. Proc Natl Acad Sci U S A 105: 17373-17378, 2008.

109. Nassenstein C, Kwong $K$, Taylor-Clark T, Kollarik M, Macglashan DM, Braun A, and Undem BJ. Expression and 
function of the ion channel TRPA1 in vagal afferent nerves innervating mouse lungs. J Physiol 586: 1595-1604, 2008.

110. Nazıroğlu M. New molecular mechanisms on the activation of TRPM2 channels by oxidative stress and ADP-ribose. Neurochem Res 32: 1990-2001, 2007.

111. Nazıroğlu M. TRPM2 cation channels, oxidative stress and neurological diseases: where are we now? Neurochem Res 36: 355-366, 2011.

112. Nazıroğlu M and Lückhoff A. A calcium influx pathway regulated separately by oxidative stress and ADP-ribose in TRPM2 channels: single channel events. Neurochem Res 33: 1256-1262, 2008.

113. Nilius B. TRP channels in disease. Biochim Biophys Acta 1772: 805-812, 2007.

114. Nilius B, Appendino G, and Owsianik G. The transient receptor potential channel TRPA1: from gene to pathophysiology. Pflugers Arch 464: 425-458, 2012.

115. Nishida M, Hara Y, Yoshida T, Inoue R, and Mori Y. TRP channels: molecular diversity and physiological function. Microcirculation 13: 535-550, 2006.

116. Numata T, Kiyonaka S, Kato K, Takahashi N, and Mori Y. Activation of TRP channels in mammalian systems. In: TRP Channels, edited by Zhu MX. Boca Raton (FL), CA: CRC Press, 2011, pp. 43-90.

117. Okada T, Shimizu S, Wakamori M, Maeda A, Kurosaki T, Takada N, Imoto K, and Mori Y. Molecular cloning and functional characterization of a novel receptor-activated TRP $\mathrm{Ca}^{2+}$ channel from mouse brain. I Biol Chem 273: 10279-10287, 1998.

118. Olah ME, Jackson MF, Li HB, Perez Y, Sun HS, Kiyonaka S, Mori Y, Tymianski M, and MacDonald JF. $\mathrm{Ca}^{2+}$-dependent induction of TRPM2 currents in hippocampal neurons. J Physiol 587: 965-979, 2009.

119. Ordaz B, Tang J, Xiao R, Salgado A, Sampieri A, Zhu MX, and Vaca L. Calmodulin and calcium interplay in the modulation of TRPC5 channel activity. Identification of a novel C-terminal domain for calcium/calmodulin-mediated facilitation. J Biol Chem 280: 30788-30796, 2005.

120. Patapoutian A, Peier AM, Story GM, and Viswanath V. Thermotrp channels and beyond: mechanisms of temperature sensation. Nat Rev Neurosci 4: 529-539, 2003.

121. Patapoutian A, Tate S, and Woolf CJ. Transient receptor potential channels: targeting pain at the source. Nat Rev Drug Discov 8: 55-68, 2009.

122. Peier AM, Moqrich A, Hergarden AC, Reeve AJ, Andersson DA, Story GM, Earley TJ, Dragoni I, McIntyre P, Bevan S, and Patapoutian A. A TRP channel that senses cold stimuli and menthol. Cell 108: 705-715, 2002.

123. Perraud AL, Fleig A, Dunn CA, Bagley LA, Launay $P$, Schmitz C, Stokes AJ, Zhu QQ, Bessman MJ, Penner R, Kinet JP, and Scharenberg AM. ADP-ribose gating of the calcium-permeable LTRPC2 channel revealed by Nudix motif homology. Nature 411: 595-599, 2001.

124. Perraud AL, Schmitz C, and Scharenberg AM. TRPM2 $\mathrm{Ca}^{2+}$ permeable cation channels: from gene to biological function. Cell Calcium 33: 519-531, 2003.

125. Perraud AL, Takanishi CL, Shen B, Kang S, Smith MK, Schmitz C, Knowles HM, Ferraris D, Li WX, Zhang J, Stoddard BL, and Scharenberg AM. Accumulation of free ADP-ribose from mitochondria mediates oxidative stressinduced gating of TRPM2 cation channels. J Biol Chem 280: 6138-6148, 2005.

126. Philipp S, Hambrecht J, Braslavski L, Schroth G, Freichel M, Murakami M, Cavalié A, and Flockerzi V. A novel capa- citative calcium entry channel expressed in excitable cells. EMBO J 17: 4274-4282, 1998.

127. Premkumar LS and Ahern GP. Induction of vanilloid receptor channel activity by protein kinase C. Nature 408: 985-990, 2000.

128. Riera CE, Menozzi-Smarrito C, Affolter M, Michlig S, Munari C, Robert F, Vogel H, Simon SA, and le Coutre J. Compounds from Sichuan and Melegueta peppers activate, covalently and non-covalently, TRPA1 and TRPV1 channels. Br J Pharmacol 157: 1398-1409, 2009.

129. Roedding AS, Gao AF, Au-Yeung W, Scarcelli T, Li PP, and Warsh JJ. Effect of oxidative stress on TRPM2 and TRPC3 channels in B lymphoblast cells in bipolar disorder. Bipolar Disord 14: 151-161, 2012.

130. Ruan T, Lin YS, Lin KS, and Kou YR. Sensory transduction of pulmonary reactive oxygen species by capsaicin-sensitive vagal lung afferent fibres in rats. J Physiol 565: 563-578, 2005.

131. Runnels LW, Yue LX, and Capham DE. TRP-PLIK, a bifunctional protein with kinase and ion channel activities. Science 291: 1043-1047, 2001.

132. Sadofsky LR, Boa AN, Maher SA, Birrell MA, Belvisi MG, and Morice AH. TRPA1 is activated by direct addition of cysteine residues to the $N$-hydroxysuccinyl esters of acrylic and cinnamic acids. Pharmacol Res 63: 30-36, 2011.

133. Salazar H, Llorente I, Jara-Oseguera A, García-Villegas R, Munari M, Gordon SE, Islas LD, and Rosenbaum T. A single N-terminal cysteine in TRPV1 determines activation by pungent compounds from onion and garlic. Nat Neurosci 11: 255-261, 2008.

134. Sano Y, Inamura K, Miyake A, Mochizuki S, Yokoi H, Matsushime $\mathrm{H}$, and Furuichi K. Immunocyte $\mathrm{Ca}^{2+}$ influx system mediated by LTRPC2. Science 293: 1327-1330, 2001.

135. Satoh $\mathrm{T}$ and Lipton SA. Redox regulation of neuronal survival mediated by electrophilic compounds. Trends Neurosci 30: 37-45, 2007.

136. Sawada Y, Hosokawa H, Matsumura K, and Kobayashi S. Activation of transient receptor potential ankyrin 1 by hydrogen peroxide. Eur J Neurosci 27: 1131-1142, 2008.

137. Schmidt M, Dubin AE, Petrus MJ, Earley TJ, and Patapoutian A. Nociceptive signals induce trafficking of TRPA1 to the plasma membrane. Neuron 64: 498-509, 2009.

138. Schmitz C, Perraud AL, Johnson CO, Inabe K, Smith MK, Penner R, Kurosaki T, Fleig A, and Scharenberg AM. Regulation of vertebrate cellular $\mathrm{Mg}^{2+}$ homeostasis by TRPM7. Cell 114: 191-200, 2003.

139. Schreiber V, Dantzer F, Amé JC, and de Murcia G. Poly (ADP-ribose): novel functions for an old molecule. Nat Rev Mol Cell Biol 7: 517-528, 2006.

140. Shimizu S, Yoshida T, Wakamori M, Ishii M, Okada T, Takahashi M, Seto M, Sakurada K, Kiuchi Y, and Mori Y. $\mathrm{Ca}^{2+}$-calmodulin-dependent myosin light chain kinase is essential for activation of TRPC5 channels expressed in HEK293 cells. J Physiol 570: 219-235, 2006.

141. Shin J, Cho H, Hwang SW, Jung J, Shin CY, Lee SY, Kim SH, Lee MG, Choi YH, Kim J, Haber NA, Reichling DB, Khasar S, Levine JD, and Oh U. Bradykinin-12-lipoxygenase-VR1 signaling pathway for inflammatory hyperalgesia. Proc Natl Acad Sci U S A 99: 10150-10155, 2002.

142. Simon SA and Liedtke W. How irritating: the role of TRPA1 in sensing cigarette smoke and aerogenic oxidants in the airways. J Clin Invest 118: 2383-2386, 2008.

143. Starkus J, Beck A, Fleig A, and Penner R. Regulation of TRPM2 by extra- and intracellular calcium. J Gen Physiol 130: 427-440, 2007. 
144. Steinberg SF. Oxidative stress and sarcomeric proteins. Circ Res 112: 393-405, 2013.

145. Story GM, Peier AM, Reeve AJ, Eid SR, Mosbacher J, Hricik TR, Earley TJ, Hergarden AC, Andersson DA, Hwang SW, McIntyre P, Jegla T, Bevan S, and Patapoutian A. ANKTM1, a TRP-like channel expressed in nociceptive neurons, is activated by cold temperatures. Cell 112: 819-829, 2003.

146. Sun HS, Jackson MF, Martin LJ, Jansen K, Teves L, Cui H, Kiyonaka S, Mori Y, Jones M, Forder JP, Golde TE, Orser BA, MacDonald JF, and Tymianski M. Suppression of hippocampal TRPM7 protein prevents delayed neuronal death in brain ischemia. Nat Neurosci 12: 1300-1307, 2009.

147. Sun L, Yau HY, Wong WY, Li RA, Huang Y, and Yao XQ. Role of TRPM2 in $\mathrm{H}_{2} \mathrm{O}_{2}$-induced cell apoptosis in endothelial cells. PLoS One 7: e43186, 2012.

148. Susankova K, Tousova K, Vyklicky L, Teisinger J, and Vlachova V. Reducing and oxidizing agents sensitize heatactivated vanilloid receptor (TRPV1) current. Mol Pharmacol 70: 383-394, 2006.

149. Szabó C, Ischiropoulos H, and Radi R. Peroxynitrite: biochemistry, pathophysiology and development of therapeutics. Nat Rev Drug Discov 6: 662-680, 2007.

150. Tabima DM, Frizzell S, and Gladwin MT. Reactive oxygen and nitrogen species in pulmonary hypertension. Free Radic Biol Med 52: 1970-1986, 2012.

151. Takahashi N, Kozai D, Kobayashi R, Ebert M, and Mori Y. Roles of TRPM2 in oxidative stress. Cell Calcium 50: 279287, 2011.

152. Takahashi N, Kuwaki T, Kiyonaka S, Numata T, Kozai D, Mizuno Y, Yamamoto S, Naito S, Knevels E, Carmeliet P, Oga T, Kaneko S, Suga S, Nokami T, Yoshida J, and Mori Y. TRPA1 underlies a sensing mechanism for $\mathrm{O}_{2}$. Nat Chem Biol 7: 701-711, 2011.

153. Takahashi N, Mizuno Y, Kozai D, Yamamoto S, Kiyonaka S, Shibata T, Uchida K, and Mori Y. Molecular characterization of TRPA1 channel activation by cysteine-reactive inflammatory mediators. Channels (Austin) 2: 287-298, 2008.

154. Takahashi N and Mori Y. TRP channels as sensors and signal integrators of redox status changes. Front Pharmacol 2: 58,2011 .

155. Talavera K, Gees M, Karashima Y, Meseguer VM, Vanoirbeek JA, Damann N, Everaerts W, Benoit M, Janssens A, Vennekens R, Viana F, Nemery B, Nilius B, and Voets T. Nicotine activates the chemosensory cation channel TRPA1. Nat Neurosci 12: 1293-1299, 2009.

156. Taylor-Clark TE, Ghatta S, Bettner W, and Undem BJ. Nitrooleic acid, an endogenous product of nitrative stress, activates nociceptive sensory nerves via the direct activation of TRPA1. Mol Pharmacol 75: 820-829, 2009.

157. Taylor-Clark TE, Kiros F, Carr MJ, and McAlexander MA. Transient receptor potential ankyrin 1 mediates toluene diisocyanate-evoked respiratory irritation. Am J Respir Cell Mol Biol 40: 756-762, 2009.

158. Taylor-Clark TE, McAlexander MA, Nassenstein C, Sheardown SA, Wilson S, Thornton J, Carr MJ, and Undem BJ. Relative contributions of TRPA1 and TRPV1 channels in the activation of vagal bronchopulmonary C-fibres by the endogenous autacoid 4-oxononenal. J Physiol 586: 3447-3459, 2008.

159. Taylor-Clark TE and Undem BJ. Ozone activates airway nerves via the selective stimulation of TRPA1 ion channels. J Physiol 588: 423-433, 2010.

160. Taylor-Clark TE and Undem BJ. Sensing pulmonary oxidative stress by lung vagal afferents. Respir Physiol Neurobiol 178: 406-413, 2011.
161. Taylor-Clark TE, Undem BJ, Macglashan DW, Jr., Ghatta S, Carr MJ, and McAlexander MA. Prostaglandin-induced activation of nociceptive neurons via direct interaction with transient receptor potential A1 (TRPA1). Mol Pharmacol 73: 274-281, 2008.

162. Tominaga M, Caterina MJ, Malmberg AB, Rosen TA, Gilbert H, Skinner K, Raumann BE, Basbaum AI, and Julius D. The cloned capsaicin receptor integrates multiple painproducing stimuli. Neuron 21: 531-543, 1998.

163. Tóth B and Csanády L. Identification of direct and indirect effectors of the transient receptor potential melastatin 2 (TRPM2) cation channel. J Biol Chem 285: 30091-30102, 2010.

164. Tousova K, Susankova K, Teisinger J, Vyklicky L, and Vlachova V. Oxidizing reagent copper-o-phenanthroline is an open channel blocker of the vanilloid receptor TRPV1. Neuropharmacology 47: 273-285, 2004.

165. Trebak M, Lemonnier L, DeHaven W, Wedel B, Bird G, and Putney JW, Jr. Complex functions of phosphatidylinositol 4,5-bisphosphate in regulation of TRPC5 cation channels. Pflugers Arch 457: 757-769, 2009.

166. Trevisani M, Siemens J, Materazzi S, Bautista DM, Nassini R, Campi B, Imamachi N, Andrè E, Patacchini R, Cottrell GS, Gatti R, Basbaum AI, Bunnett NW, Julius D, and Geppetti P. 4-Hydroxynonenal, an endogenous aldehyde, causes pain and neurogenic inflammation through activation of the irritant receptor TRPA1. Proc Natl Acad Sci U S A 104: 13519-13524, 2007.

167. Trostchansky A and Rubbo H. Nitrated fatty acids: mechanisms of formation, chemical characterization, and biological properties. Free Radic Biol Med 44: 1887-1896, 2008.

168. Uchida $\mathrm{K}$ and Shibata T. 15-Deoxy- $\Delta^{12,14}$-prostaglandin $\mathrm{J}_{2}$ : an electrophilic trigger of cellular responses. Chem Res Toxicol 21: 138-144, 2008.

169. Vazquez G, Wedel BJ, Aziz O, Trebak M, and Putney JW, Jr. The mammalian TRPC cation channels. Biochim Biophys Acta 1742: 21-36, 2004.

170. Viola A and Luster AD. Chemokines and their receptors: drug targets in immunity and inflammation. Annu Rev Pharmacol Toxicol 48: 171-197, 2008.

171. Voets T, Talavera K, Owsianik G, and Nilius B. Sensing with TRP channels. Nat Chem Biol 1: 85-92, 2005.

172. Vyklický L, Lyfenko A, Sušánková K, Teisinger J, and Vlachová V. Reducing agent dithiothreitol facilitates activity of the capsaicin receptor VR-1. Neuroscience 111: 435441, 2002.

173. Wang S and Chuang HH. C-terminal dimerization activates the nociceptive transduction channel transient receptor potential vanilloid 1. J Biol Chem 286: 40601-40607, 2011.

174. Wang S, Dai Y, Fukuoka T, Yamanaka H, Kobayashi K, Obata K, Cui X, Tominaga M, and Noguchi K. Phospholipase $\mathrm{C}$ and protein kinase A mediate bradykinin sensitization of TRPA1: a molecular mechanism of inflammatory pain. Brain 131: 1241-1251, 2008.

175. Wehage E, Eisfeld J, Heiner I, Jüngling E, Zitt C, and Lückhoff A. Activation of the cation channel long transient receptor potential channel 2 (LTRPC2) by hydrogen peroxide. A splice variant reveals a mode of activation independent of ADP-ribose. J Biol Chem 277: 23150-23156, 2002.

176. Wilson L, Butcher CJ, and Kellie S. Calcium ionophore A23187 induces interleukin- 8 gene-expression and protein secretion in human monocytic cells. FEBS Lett 325: 295-298, 1993.

177. Wong CO, Sukumar P, Beech DJ, and Yao XQ. Nitric oxide lacks direct effect on TRPC5 channels but suppresses 
endogenous TRPC5-containing channels in endothelial cells. Pflugers Arch 460: 121-130, 2010.

178. Xu H, Blair NT, and Clapham DE. Camphor activates and strongly desensitizes the transient receptor potential vanilloid subtype 1 channel in a vanilloid-independent mechanism. J Neurosci 25: 8924-8937, 2005.

179. Xu SZ, Sukumar P, Zeng F, Li J, Jairaman A, English A, Naylor J, Ciurtin C, Majeed Y, Milligan CJ, Bahnasi YM, Al-Shawaf E, Porter KE, Jiang LH, Emery P, Sivaprasadarao A, and Beech DJ. TRPC channel activation by extracellular thioredoxin. Nature 451: 69-72, 2008.

180. Yamamoto S, Shimizu S, Kiyonaka S, Takahashi N, Wajima T, Hara Y, Negoro T, Hiroi T, Kiuchi Y, Okada T, Kaneko S, Lange I, Fleig A, Penner R, Nishi M, Takeshima H, and Mori Y. TRPM2-mediated $\mathrm{Ca}^{2+}$ influx induces chemokine production in monocytes that aggravates inflammatory neutrophil infiltration. Nat Med 14: 738-747, 2008.

181. Yamamoto S, Wajima T, Hara Y, Nishida M, and Mori Y. Transient receptor potential channels in Alzheimer's disease. Biochim Biophys Acta 1772: 958-967, 2007.

182. Yang KT, Chang WL, Yang PC, Chien CL, Lai MS, Su MJ, and $\mathrm{Wu}$ ML. Activation of the transient receptor potential M2 channel and poly(ADP-ribose) polymerase is involved in oxidative stress-induced cardiomyocyte death. Cell Death Differ 13: 1815-1826, 2006.

183. Yoshida T, Inoue R, Morii $T$, Takahashi N, Yamamoto $S$, Hara Y, Tominaga M, Shimizu S, Sato Y, and Mori Y. Nitric oxide activates TRP channels by cysteine S-nitrosylation. Nat Chem Biol 2: 596-607, 2006.

184. Zeng XK, Dai J, Remick DG, and Wang X. Homocysteine mediated expression and secretion of monocyte chemoattractant protein-1 and interleukin-8 in human monocytes. Circ Res 93: 311-320, 2003.

185. Zhang W, Chu X, Tong Q, Cheung JY, Conrad K, Masker $\mathrm{K}$, and Miller BA. A novel TRPM2 isoform inhibits calcium influx and susceptibility to cell death. J Biol Chem 278: 16222-16229, 2003.

186. Zhang WY, Hirschler-Laszkiewicz I, Tong Q, Conrad K, Sun SC, Penn L, Barber DL, Stahl R, Carey DJ, Cheung JY, and Miller BA. TRPM2 is an ion channel that modulates hematopoietic cell death through activation of caspases and PARP cleavage. Am J Physiol Cell Physiol 290: C1146-C1159, 2006.

187. Zhong J, Minassi A, Prenen J, Taglialatela-Scafati O, Appendino $G$, and Nilius B. Umbellulone modulates TRP channels. Pflugers Arch 462: 861-870, 2011.

188. Zhong J, Pollastro F, Prenen J, Zhu ZM, Appendino G, and Nilius B. Ligustilide: a novel TRPA1 modulator. Pflugers Arch 462: 841-849, 2011.

189. Zurborg S, Yurgionas B, Jira JA, Caspani O, and Heppenstall PA. Direct activation of the ion channel TRPA1 by $\mathrm{Ca}^{2+}$. Nat Neurosci 10: 277-279, 2007.

190. Zygmunt PM, Petersson J, Andersson DA, Chuang H, Sørgård M, Di Marzo V, Julius D, and Högestätt ED. Vanilloid receptors on sensory nerves mediate the vasodilator action of anandamide. Nature 400: 452-457, 1999.
Address correspondence to: Prof. Yasuo Mori

Department of Synthetic Chemistry and Biological Chemistry Graduate School of Engineering Kyoto University

Katsura Campus, Nishikyo-ku Kyoto 615-8510

Japan

E-mail: mori@sbchem.kyoto-u.ac.jp

Date of first submission to ARS Central, August 30, 2013; date of acceptance, September 16, 2013.

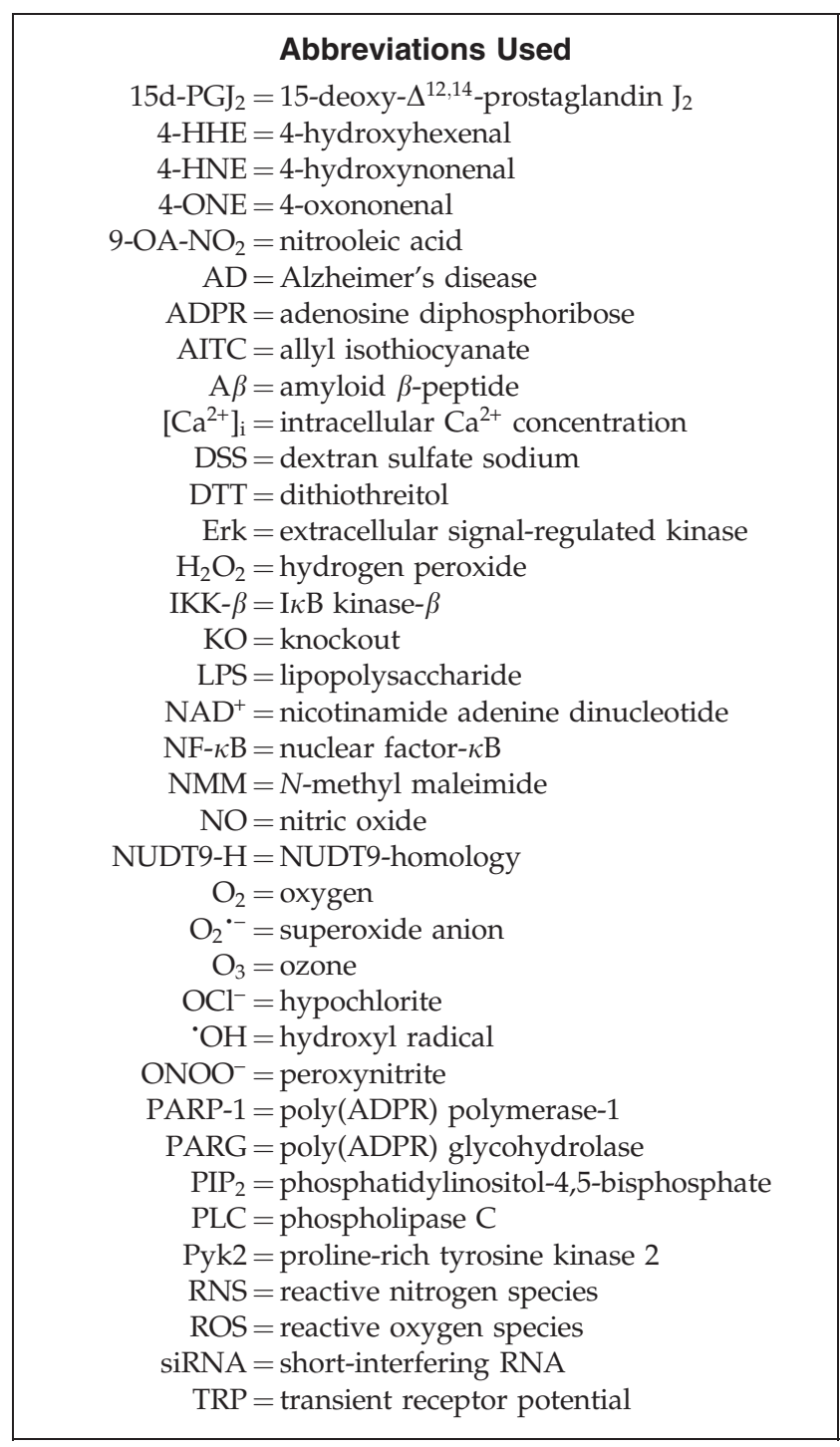

